\title{
The Ambiguous Legacy of Ngô Đình Diệm in South Vietnam's Second Republic (1967-1975)
}

n November 2, 1971, Sài Gòn's Notre Dame Basilica is packed with
spectators, and the streets outside teem with throngs of onlookers. Vietnam Press, the Republic of Vietnam's official news service, reports that over five thousand people turn out for the commemorations, which continue later that afternoon at the Mạc Đĩnh Chi Cemetery. In attendance are a number of political notables, including the president's wife, Vice President Trần Văn Hương, several cabinet ministers, and even former Generals Đỗ Mậu and Lê Văn Nghiêm, both noted enemies of the man being honoured. ${ }^{1}$ At the cemetery, standing next to the fallen man's grave, is Trương Công Cừu, Chairman of the Revolutionary Social Humanist Party [Việt Nam Nhân Xã Cách Mạng Đảng], or Nhân Xã, widely known in political circles as a thinly veiled attempt to revive the former governing Cần Lao Party. Trương Công Cừu eulogizes the man they have all gathered to remember: "He was the incarnation of the noblest ideals of our race and mankind. Animated by a glorious ideal from childhood, he consecrated his whole existence to the righteous cause ... he brought South Vietnam from a dependent, exhausted, disordered and disorganized position into the ranks of a sovereign, prosperous and well-disciplined nation, respected by the whole world, friends and foes alike." ${ }^{2}$ But the death of the man to whom Truoong

Journal of Vietnamese Studies, Vol. 11, Issue 1, pps. 1-75. ISSN 1559-372X, electronic 1559-3738. (c) 2016 by The Regents of the University of California. All rights reserved. Please direct all requests for permission to photocopy or reproduce article content through the University of California Press' Rights and Permissions website, at http://www.ucpressjournals.com/reprintinfo.asp. DOI: 10.1525/vs.2016.11.1.1. 
Công Cửu referred was not, however, a recent passing - in 1971, he had been dead for eight years-and his demise in 1963 had brought far more substantial crowds into the streets of Sài Gòn, who cheered and danced for joy rather than mourn the news of his downfall. ${ }^{3}$ As these very different responses to his death suggest, Ngô Đình Diệm, the Republic of Vietnam's first president, left an ambivalent but intriguingly fluid legacy, his star rising and falling in response to evolving trends and perceptions that emerged long after his death.

Ngô Đình Diệm has long been caricatured in English-language studies of the Vietnam War as little more than an American puppet, or a hopelessly out-of-touch traditional "mandarin" unable to comprehend, much less respond to, the rapidly changing world around him. ${ }^{4}$ But in recent years, he has been the subject of considerable attention by a new generation of Vietnamese-language proficient historians who have revealed him to be an idealistic albeit conservative nation-builder who resisted domestic and American pressure to compromise his vision. ${ }^{5}$ Nonetheless, although Ngô Đình Diệm was a more complex and sophisticated leader than most accounts have traditionally acknowledged, the divergent attitudes toward his death portrayed above are indicative of his controversial status, both among scholars and in South Vietnam following the 1963 coup that deposed him. Consistently misrepresented as an ephemeral figure in subsequent South Vietnamese politics, Ngô Đình Diệm is mistakenly assumed to have been all but forgotten following the celebrations greeting news of his death. One particularly influential example, Frances FitzGerald's Fire in the Lakewhich won the National Book Award, Pulitzer Prize, and Bancroft Prizeasserts that "the people of Saigon rarely spoke of the Diem regime" after his death, a passage still cited without scrutiny in recent scholarship. ${ }^{6}$

In fact, as we shall see, Ngô Đình Diệm's memory loomed large over South Vietnam's Second Republic, which faced many of the same lingering challenges that he had confronted and in some cases created. Heated discussions of his legacy featured prominently in Sài Gòn's raucous but at times relatively free press, especially after revelations from the Pentagon Papers in 1971 appeared to many commentators to cast him in a more sympathetic light. Ngô Đình Diệm’s image and governing style also proved remarkably persistent, with the Nhân Xã Party striving to revitalize the Diệmist Cần Lao 
brand, and with President Nguyễn Văn Thiệu—who had led the final attack on Ngô Đình Diệm’s palace-courting former Cần Lao Party architects and emulating key political structures of his predecessor's regime. Additionally, impressions of Ngô Đình Diệm's personality and policies informed popular responses to the governments that succeeded him, whose leaders were measured-if not defined-by past relations with the former president or the junta that ousted and murdered him. Mounting public criticism of Nguyễn Văn Thiệu was conditioned by bitter experiences of similar political models forged under Ngô Đình Diệm, whose name, along with the Cần Lao moniker, became something of a pejorative levied within South Vietnam's political class to express despair over Nguyễn Văn Thiệu's perceived authoritarianism. Likewise, figures such as Dương Văn Minh, the public face of the 1963 coup, would both enjoy considerable esteem and suffer vicious but localized resentment for their role in toppling Ngô Đình Diệm. During the Nguyễn Văn Thiệu era, Dương Văn Minh in particular emerged as the emblematic leader of a diverse coalition of anti-military civilians who coalesced against Nguyễn Văn Thiệu and the Nhân Xã Party much as they had in opposition to Ngô Đình Diệm and the Cần Lao.

Throughout the Second Republic then, Ngô Đình Diệm remained an evocative symbol with strong emotional connotations-both positive and, more often, negative-according to the outlook of the beholder. Long after his passing, he served as a symbolic wedge, reinforcing South Vietnam's all but intractable social fragmentation. This article challenges the prevailing notion that Ngô Đình Diệm was a fleeting presence in South Vietnamese politics after his death by examining his contested legacy during the Second Republic. It analyzes the political impact of the regional and religious polarization that he posthumously aggravated and prolonged, the instructive limitations of the neo-Cần Lao Nhân Xã Party, the intense but fleeting Diệmist revival in 1971, and the ways in which Ngô Đình Diệm's memory informed criticism of his successor Nguyễn Văn Thiệu, which reached a crescendo after the latter's widely reviled unopposed re-election in 1971. Although recent scholarship has devoted significant effort to reconsidering the Ngô Đình Diệm era, contemporaneous South Vietnamese interpretations of his reign have received much less attention. In fact, Ngô Đình Diệm's ambivalent status within South Vietnam had a considerable impact 
on later political developments, providing a basic vocabulary and comparative framework for assessing subsequent state affairs, shaping perceptions of and reactions to his successors, and exacerbating the underlying social tensions that his contested memory came to symbolize. As this article hopes to demonstrate, Ngô Đình Diệm's lasting posthumous impact on South Vietnam's Second Republic is a critical dimension to consider in evaluating his legacy.

\section{Political Dynamics of the Late Ngô Đình Diệm Era}

In hindsight, many South Vietnamese observers would come to date the turning point for the Ngô Đình Diệm regime to the abortive effort by a group of dissident paratroopers to depose him on November 11, 1960. His palace surrounded, the President appeared to defer to the rebels' demands, all the while summoning loyal reinforcements who arrived the following morning to crush the insurgents along with a crowd of several hundred anti-government civilian sympathizers. ${ }^{7}$ But though the coup attempt failed to dislodge the increasingly beleaguered regime, it came to represent the moment when both the army and civilian political groups began losing faith in the government, and when regional and religious equilibrium deteriorated. ${ }^{8}$ In the years that followed, the government found itself beset with a litany of crises, including a burgeoning rural communist insurrection, religious violence, discontent in the military, growing popular unrest, and a widening schism with its ever more intrusive American ally. As we shall see, these familiar recurring developments would once again emerge after lingering grievances from the Ngô Đình Diệm era intensified during the Second Republic, under Nguyễn Văn Thiệu.

Of particular concern for many government critics was the encroachment into public affairs by the Cần Lao Party, the clandestine political network inspired by Ngô Đình Diệm’s guiding philosophy of Personalism [Nhân vị], but increasingly perceived as an instrument for advancing the Ngô family's private interests. 9 "By 1960," future ambassador to the United States Bùi Diễm recalled, "the government had become, in essence, a family-run oligarchy. Hanging over everything like a pall were the police-state measures that kept the jails filled and silenced dissident voices," he added, "and all this was complemented by an expanding guerrilla war, organized by the 
remnants of the Vietminh infrastructure but drawing on the support of badly disaffected people at every level of society." ${ }^{10}$ In the civil service, the promotion of unqualified Cần Lao Party members was especially resented, resulting in a wave of resignations. "Professionalism was disappearing," lamented Nguyễn Hữu Hanh, who stepped down as Director of the Central and Commercial Credit Banks in 1960 to protest their use as "a financial and political support for Nhu's Can Lao Party and Diem's family members' business undertakings." ${ }^{11}$ The Cần Lao Party had an equally demoralizing effect on the military, where, at least according to Army of the Republic of Vietnam [Quân lực Việt Nam Cộng hòa] (ARVN) Ninth Division commander Lâm Quang Thi, "it was a well-known fact that to advance under Diem's regime, one had to be a member of the Can Lao Party, a Catholic, and a resident of Central Vietnam." ${ }^{12}$ Like Bùi Diệm, Lâm Quang Thi also saw 1960 as the year when "it was apparent to everyone that President Diem's one-man rule, the excess and corruption of his entourage, and the growing power of a centralized oligarchy had caused dissatisfaction and resentment in the population and in the army." 13

In January 1960, communist guerillas overran a regiment of the ARVN Twenty First Division in Tây Ninh Province, the first in a series of assaults sweeping the countryside that year. Cited in the Caravelle Manifesto [Tuyên ngôn Caravelle], an open letter signed in April by eighteen prominent civilian leaders urging administrative reforms, the episode in Tây Ninh also touched a nerve within ARVN. The defeat was attributed by many officers to the hasty promotion of inexperienced commander Trần Thanh Chiêu, dismissed as nothing more than "a trusty Cần Lao Catholic subordinate" by ARVN Military Security Service Director Đỗ Mậu. ${ }^{14}$ Himself a Cần Lao member, albeit an ever more disillusioned one, Đỗ Mậu would regard the paratroopers' subsequent November "mutiny" as "the final link in a long chain of political and military crises which the Diệm regime faced due to its widespread clumsiness and lack of preparation." ${ }^{15}$ And though he had abstained from the 1960 rebellion, by 1963, Đỗ Mậu was working with Trần Kim Tuyến, yet another disgruntled former loyalist, and later, with Generals Dương Văn Minh, Trần Văn Đôn and Lê Văn Kim, to eliminate Ngô Đình Diệm. Crucially, 1960 also saw the Dương Văn Minh, Trần Văn Đôn and Lê Văn Kim trio holding their first clandestine meetings to discuss a mutual 
"sense of discontent" over the Ngô family's "exclusive exploitation of the nation's resources." Three years later, citing alarm over the government crackdown against Buddhist and student demonstrators, the generals had determined that Ngô Đình Diệm and his brother Ngô Đình Nhu had to go. ${ }^{16}$

Arguably the Ngô Đình Diệm regime’s defining crisis, the 1963 Buddhist uprising has come to be regarded as almost preordained-the inevitable result of what Western observers saw as the inherent unsuitability of a Catholic leader in majority Buddhist Vietnam. For David Halberstam, it was a truism that "by Vietnamese standards, there was little legitimacy; Diem ... an American creation... was a Catholic in a Buddhist country, a Central Vietnamese in the South,... [and] a mandarin, a member of the feudal aristocracy in a country swept by revolution." ${ }^{17}$ But before the Vesak Day shootings on May 8, 1963-when, in an act one eyewitness described as "inhuman repression," nine Buddhist demonstrators were killed by government security forces in Huế-relations between Catholics, the state, and South Vietnam's Buddhist population were more stable than subsequent events would suggest, if still somewhat less than cordial. ${ }^{18}$ Although Catholics were historically subject to state persecution, during the reign of Emperor Minh Mạng (1820-1841) for instance, there had also been periods of official tolerance following the ascension of Gia Long (Nguyễn Phúc Ánh) in 1802. And despite their portrayal in post-war national histories as something of a colonialist fifth column, Catholic communities in Vietnam had a far more complex relationship with radical politics than stereotypical depictions of Ngô Đình Diệm partisans suggest. ${ }^{19}$ Catholicism in South Vietnam was also characterized by considerable diversity. While northerndominated political groups like the Cần Lao and later, Nhân Xã, the Greater Solidarity Force [Lực lượng Đại Đoàn kêt] (GSF), or the Catholic Citizens' Bloc [Khối Công dân Công giáo] (CCB) had a reputation for uncompromising anti-communism and staunch support for the war, southern Catholic intellectuals, in publications such as Hy Vọng [Hope], Đối Diện [Face-toFace] or Sống Đạo [Faithful Living], led calls to negotiate with the National Liberation Front [Mặt trận Dân tộc Giải phóng Miền Nam] (NLF), and were among the government's most prominent and persistent critics. ${ }^{20}$ Indeed, during the 1967 presidential election, many Catholics rebuffed Nguyễn Văn Thiệu, a Catholic convert, opting instead to support Trần Văn Hương, the 
southern Buddhist still reviled by many Buddhists for suppressing their protests during his brief 1964 stint as prime minister. ${ }^{21}$

South Vietnamese Buddhists were likewise divided over the question of relations with the state, with Thích Trí Quang advocating forceful resistance against Ngô Đình Diệm even as Thích Tâm Châu pursued a settlement with the embattled president, at least until the regime's resort to violence ultimately forced his hand. This rift crystallized during the Second Republic after Nguyễn Văn Thiệu's sponsorship of Thích Tâm Châu's small, northern-dominated Quốc Tự faction alienated the much larger Central Vietnamese Ấn Quang bloc, an act Dương Văn Minh compared to French “divide and rule" tactics and to Ngô Đình Diệm’s “unacceptable” intervention in Buddhist affairs. ${ }^{22}$ Both emerging factions, however, were motivated by a collective sense of anxiety that Buddhism was fading from Vietnamese life. Indeed, the Buddhist Struggle Movement [Phong trào Phật giáo Tranh đấu] that confronted Ngô Đình Diệm in the early 1960s drew on a longstanding Buddhist Revival [Chấn hưng Phật giáo] tradition from the 1920s, which called for a return to Buddhist principles and insisted that Buddhism belonged at the core of Vietnamese national identity. ${ }^{23}$

This drew the Struggle Movement into conflict with local Catholics led by Ngô Đình Thục, the Archbishop of Huế and Ngô Đình Diệm’s older brother, a confrontation with lasting consequences that would linger throughout the Second Republic. Hoping to turn Central Vietnam into a Catholic heartland, Ngô Đình Thục strove to assert Catholic power in the region, and his extravagant efforts to this end and heavy-handed dealings with local Buddhists contributed greatly to the May 8 tragedy. Following the massacre, the crisis that would precipitate the president's downfall escalated rapidly after Ngô Đình Diệm lost patience with younger brother Ngô Đình Cẩn's conciliatory approach, instead coming to favor Ngô Đình Nhu and Ngô Đình Thục's repressive tactics. ${ }^{24}$ The ensuing crackdown resulted in the iconic, globally resonant self-immolation of Thích Quảng Đức on June 11, the much-condemned August 21 police pagoda raids, and the rapid deterioration of relations between Buddhists, Catholics, and the state. Thus, in spurning the efforts of Ngô Đình Cẩn and Thích Tâm Châu to contain these simmering religious hostilities, Ngô Đình Diệm elevated latent but previously manageable Catholic-Buddhist tensions to a new level of intensity, 
provoking an outburst of violence and resentment that was by no means preordained even in the immediate aftermath of Vesak Day. Perhaps the most enduring legacy of his tenure, this eruption of mostly dormant religious animosities created immense long-term political damage that subsequent governments struggled to repair.

In Washington, State Department officials were alarmed by the government's inability to dampen the protests, and embarrassed by the growing public relations nightmare caused by the prolonged standoff. ${ }^{25}$ A turning point came on August 24, when a State Department cable to the Sài Gòn Embassy, issued while senior officials were away for the weekend, instructed Ambassador Henry Cabot Lodge Jr. to demand Ngô Đình Nhu's removal, and further cautioned that if "Diem remains obdurate and refuses, then we must face the possibility that Diem himself cannot be preserved." ${ }^{26}$ But while President John F. Kennedy later clarified to Ambassador Lodge that he "reserve[d] a contingent right to change course and reverse previous instructions," and in spite of his grave doubts about what a coup might bring, he would never waver from the policy of deposing Ngô Đình Diệm should he continue to resist American-backed reforms. ${ }^{27}$ On November 1, having secured both American blessing and the loyalty of General Tôn Thất Đính, whose troops were strategically positioned surrounding Sài Gòn, the generals-Dương Văn Minh, Trần Văn Đôn and Lê Văn Kim-made their move, their forces capturing Ngô Đình Diệm and his brother Ngô Đình Nhu the following morning and executing them in the back of an armored personnel carrier. South Vietnam's First Republic had come to an abrupt and unseemly end.

\section{Putting the Pieces Back Together}

Although the generals and their American collaborators were convinced that eliminating Ngô Đình Diệm was necessary to stem the state's spiralling disintegration, ousting the president only accelerated the crisis it was intended to resolve, ushering in a period of utter political chaos. From the outset, the generals' self-proclaimed Revolution [Cuộc Cách mạng] lacked a legal basis, and was characterized by what one account describes as the "narrow minds and visions and the boundless ambitions" of its leaders. ${ }^{28}$ Worse still for the White House was Dương Văn Minh’s apparent willingness 
to negotiate a settlement with the communists, who wasted little time exploiting the tumult in Sài Gòn to expand and consolidate their control in the countryside, building on the wave of momentum they had enjoyed from the start of the 1963 campaign. When resolutely anti-communist officer Nguyễn Khánh launched the Readjustment [Cuộc Chỉnh lý], a second coup sweeping aside the initial triumvirate of generals some three months later, he enjoyed immediate American support. ${ }^{29}$ "Perhaps," reflected former Foreign Minister Vũ Văn Mẫu on the Dương Văn Minh trio, “intoxication with victory and fame had lulled these generals toward defeat." 30

Enjoying none of the initial prestige associated with those who had overthrown Ngô Đình Diệm, and with an even more limited popular support base, the aloof and uncharismatic Nguyễn Khánh likewise struggled to restore political order. Initially, he sought to partner with the Đại Việt Party [Đại Việt Quốc dân Đảng], a regionally fragmented clandestine political network which eschewed grassroots organization for efforts to command power by infiltrating top bureaucratic positions. Hoping that association with Đại Việt politicians—-known for their hostility to Ngô Đình Diệmwould defuse allegations that he intended to restore Catholic Ngô family partisans to power, Nguyễn Khánh soon fell out with the party after uncovering a February Đại Việt plot to seize control of his government from within. ${ }^{31}$ Instead, he turned for support to a loose coalition of Buddhists and students, whose demands included the May 9, 1964 execution of staunch Catholic Ngô Đình Cẩn as proof of Nguyễn Khánh's anti-Ngô family credentials, an event which further aggravated South Vietnam's chronic Catholic-Buddhist rupture. Within the military, Nguyễn Khánh also came to rely on the Young Turks [Nhóm các tướng trẻ], a group of junior officers including Nguyễn Cao Kỳ, Nguyễn Chánh Thi, and Nguyễn Văn Thiệu, who rose to prominence by suppressing a failed anti-Nguyễn Khánh military coup led by Catholic generals in September 1964. Their influence further enhanced after putting down a second abortive Catholic officers' coup in February 1965, the Young Turks capitalized on the chaos by removing Nguyễn Khánh from power altogether, replacing him with the gregarious but impulsive Nguyễn Cao Kỳ. All the while, the prolonged CatholicBuddhist rivalry saw successive politicians dismissed from the increasingly titular position of prime minister. In February 1965, Trần Văn Hương was 
replaced by Phan Huy Quát after a wave of Buddhist protests, only for Phan Huy Quát, a northern Buddhist Đại Việt, to be pressured into resignation by hostile Catholic groups, prompting Nguyễn Cao Kỳ to declare an end to the shaky façade of civilian rule altogether in June $1965 .^{32}$

Meanwhile, in Vietnam's Central Highlands, yet another toxic legacy of the Ngô Đình Diệm era became apparent with the sudden emergence of the United Front for the Liberation of Oppressed Races [Front de Lutte des Races Opprimés] (FULRO), an alliance of ethnic minorities opposed to Ngô Đình Diệm's longstanding policy of flooding the once-autonomous highlands with ethnic Vietnamese settlers. In September 1964, US-trained FULRO special forces swept across Buôn Mê Thuột Province denouncing the government's "systematic genocidal policy" and demanding the withdrawal of "Vietnamese imperialists" from the region. A second December 1965 uprising, after talks with the government broke down, was forcibly suppressed, resulting in the execution of four FULRO rebels and the exile of its more militant leaders to Cambodia. Nonetheless, tensions between Sài Gòn and the highlands minorities represented yet another lingering fissure from the Ngô Đình Diệm era that plagued the Second Republic, not least in the form of decisive pockets of ethnic minority support for communist forces in the highlands as they prepared their final 1975 offensive. ${ }^{33}$

The FULRO uprising came as White House officials, alarmed by communist progress in the countryside, prepared a vast expansion of US involvement in the war to follow the 1964 presidential election, in spite of grave if private doubts that escalation could succeed in bringing Hà Nội to heel. ${ }^{34}$ Beginning in the spring of 1965, American troop deployments combined with massive economic investment fundamentally transformed South Vietnamese society, a process which, as we shall see, had the effect of recasting the First Republic from a time of political turmoil to one of relative tranquility in the memories of many South Vietnamese. But while the introduction of American ground troops managed to check communist military advances, it did little to stabilize South Vietnam's protracted political chaos.

In March 1966, a second far more substantial Buddhist uprising in Central Vietnam attracted the sympathy of thousands of students, teachers, civil servants, and even the mayor of Đà Nẵng, resulting in the effective loss 
of Huế and Đà Nẵng from central government control. What began as a power struggle between Nguyễn Cao Kỳ and Nguyễn Chánh Thi, the popular Buddhist commander of I Corps in Central Vietnam, soon acquired familiar political, regional and religious implications after Buddhist protesters led by Thích Trí Quang seized on local resentment over Nguyễn Chánh Thi's March 11 dismissal to demand an end to military rule, perceived Buddhist alienation, and the rapidly intensifying American-backed war. Particularly effective in motivating the crowd was a series of Huế radio broadcasts in which Thích Trí Quang warned that Nguyễn Chánh Thi's removal was intended to clear the way for the return to power of Ngô Đình Diệm loyalists. Local ARVN discipline began to break down as a growing number of Buddhist soldiers disobeyed orders and joined the insurrection. And in Huế, angry crowds burned the American Consulate and United States Information Service (USIS) library to the ground, defying even Thích Trí Quang's efforts to rein in the violence. Meanwhile, back in Sài Gòn, counter-demonstrations by Catholic groups, alarmed at their prospects under a Buddhist-dominated state and concerned that the disorder would embolden the communists, raised the pressure on Nguyễn Cao Kỳ to respond. ${ }^{35}$ As it had with FULRO, the military opted for a show of force, with Nguyễn Cao Kỳ ordering a May 15 assault on Đà Nẵng that ultimately won back control of the central coast after weeks of bitter street-to-street guerrilla combat, resulting in the deaths of an estimated one hundred protesters and the arrest of Thích Trí Quang and thousands of supporters. ${ }^{36}$

With the protesters suppressed but far from placated, the 1966 demonstrations represented yet another manifestation of South Vietnam's by now virtually intractable polarization, accompanied by a prevailing sense of cynicism and widespread suspicion of the state. Though clearly exacerbated by the anarchy that followed the 1963 coup, the ensuing explosion of street violence had been ultimately set in motion by the Ngô family, whose nepotism and authoritarianism had activated South Vietnam's underlying social fault-lines, resulting in rapid political deterioration already well underway before the ineffectual coup that deposed them. And while the protesters in Central Vietnam had proved no match for American-backed ARVN firepower, the 1966 Uprising revealed once again that the government's political bankruptcy could not be resolved by brute force alone. 
In a tacit acknowledgment that the military had disappointed the hopeful crowds of November 1963, Nguyễn Cao Kỳ conceded that the assault on Đà Nẵng would be followed by elections and a new constitution, offering the promise of reform in exchange for domestic order, and hoping to shore up dwindling support from domestic and American constituents, to whom the regime was increasingly beholden. But behind closed doors in Washington and Sài Gòn, the elections were regarded as no more than a means of improving the government's public image and legalizing the status quo, strictly intended to consolidate rather than contest the military's power. As Ambassador Lodge put it, "the military is the only group which has experience or competence in managing the country... [They] will need to run the country for some time, and if we give any real power to civilians, the military will overthrow the government." 37 Civilian politicians were likewise under few illusions that the military was sincere in professing to stage an honest contest. For many observers, the prospect of elections raised at best measured hopes of a more responsive state, while reviving persistent anxieties about what, if anything, could succeed the disgraced Ngô Đình Diệm regime. As the southern Catholic journalist and politician Võ Long Triều recalls:

In the last months and days of the First Republic, many members of the Catholic intellectual Pax Romana Movement, myself included, were constantly discussing the South's leadership "crisis," in which the mass of public opinion was discontent that the brothers of President Ngô Đình Diệm, Ngô Đình Nhu and Ngô Đình Cẩn, were enforcing an undemocratic system of nepotism that had lost the people's faith... However, there were also many brothers among us who supported President Ngô Đình Diệm, who often posed the question: "apart from President Ngô Đình Diệm, who is more worthy of the task of administrating the country?" It was a question that nobody could answer decisively. ${ }^{38}$

To be sure, Ngô Đình Diệm was far from solely responsible for the breakdown of the First Republic's precarious social order. After all, the overlapping confrontations that exploded during the last days of his rule and its aftermath reflected deep underlying social schisms, and were orchestrated by a host of headstrong personalities. Still, as we have seen, Ngô Đình Diệm's overbearing response to the Buddhist crisis in particular upset South Vietnam's delicate political balance, reviving and intensifying latent 
grievances that would always prove a challenge to redress. Accordingly, as his successors struggled to restore order, the fallen president, however accurately, came to personify the enduring animosities that his actions had helped to unleash.

\section{Building the Second Republic}

If the 1967 elections then were largely an attempt by the military and the United States to construct a veneer of legality for the status quo of military rule, they were also an implicit acknowledgement that political consensus and an increased sense of popular participation in government were necessary to soothe South Vietnam's longstanding political, regional and religious tensions, which had erupted during the final years of Ngô Đình Diệm’s rule. Still, staging elections was seen as no small gamble in both Washington and Sài Gòn, tempting the very real possibility that peaceful political competition could spiral out of control, in turn inviting yet another unpopular military intervention. We "ought to take out coup insurance against this risk," one White House directive pithily suggested. ${ }^{39}$ And as the new Constitutional Assembly [Quốc hội Lập hiến] delegates tasked with drafting election laws and a new constitution soon discovered, the social fragmentation that accelerated during the last year of Ngô Đình Diệm's reign would continue to exacerbate the already considerable challenge of creating a new legal framework to put the pieces back together again.

When, on January 10, 1967, the Assembly presented the Armed Forces Council [Hội đồng Quân lực] with a preliminary constitution, the draft was immediately attacked from all sides, with demands at times hinging on what seemed to American observers like quaint and frivolous objections. Edward Lansdale, the veteran US operative tasked with overseeing the drafting, complained of the delegates' "superstition in the form of the mesmeric arcane" when delays were caused by "last minute editorial juggling" so that the phrase "we the people" could be revised to result in a more astrologically auspicious word count. ${ }^{\circ}$ These dismissive attitudes overlooked, however, the high degree of imagery and symbolism imbued in the often performative dialogues between rival political forces in South Vietnam, broadly but by no means strictly divided along overlapping northern-southern, CatholicBuddhist, and pro and anti-military poles. 
Northern Catholic political groups like Nguyễn Gia Hiên's GSF, for example, focused their efforts on condemning the deletion of an earlier reference to a "supreme being" [Đấng Tối cao] from the constitution's preamble. After Catholic delegates rejected United Buddhist Association Director [Viện trưởng Viện Hóa đạo] Thích Tâm Châu’s compromise suggestion of "merciful being" [Đấng Tư bi] for being "too Buddhist," some 2,500 Catholic protesters surrounded the Assembly on March 31, demanding that Assembly Chairman Phan Khắc Sưu restore the phrase. Phan Khắc Sửu, insisting that he was not an atheist, informed them that there was nothing he could do, as the Assembly would not meet again until April 6, after the constitution was scheduled for promulgation. Instead, he suggested that the demonstrators confer with the military-led National Leadership Council [Ủy ban Lãnh đạo Quốc gia] (NLC) responsible for ratifying the draft, whereupon the crowd headed en masse toward the heavily guarded Independence Palace, demanding to speak with Prime Minister Nguyễn Cao Kỳ. Three hours later, Nguyễn Cao Kỳ emerged only to declare that while he personally had no objection to the phrase "supreme being," the Assembly alone had the authority to change the wording of the document-by which point most of the crowd had grown bored and dispersed. ${ }^{41}$ The following day, a New York Times report on the fracas downplayed the debate over the preamble's wording as "typical Vietnamese fondness for the occult." 42

But what appeared to many outsiders like a trifling and parochial confrontation was actually the latest round of rhetorical jousting for influence over the constitutional process, played out in the relatively safe realm of symbolism after both sides drew back from the violence that characterized the post-Ngô Đình Diệm interregnum. In fact, as Nguyễn Gia Hiên later explained to a US Embassy officer, the Catholic protesters did not actually expect their demonstration to change the phrasing of the constitution, though they nonetheless seized on the occasion to display their determination, revealing a pragmatic deployment of symbolic protest to stake a claim for themselves in the new political system. Likewise, Nguyễn Cao Kỳ's public refusal to intercede, the embassy suspected, was most likely little more than a performative act of defiance meant to mollify military critics opposed even to the constitution's token concessions to civilians. Given the conspicuous arrival of many of the Catholic protesters in ARVN jeeps, the embassy 
concluded, the entire affair had been more spectacle than genuine standoff, perhaps even pre-arranged to allow both parties to project resolve to their opponents and constituents. ${ }^{43}$

Nguyễn Gia Hiên's rivals, on the other hand, were no less adept at employing allegory to project political intent. During the Assembly's March 18 morning session, on the day when delegates voted on the constitution for the final time before sending it to the NLC for review, Nguyễn Đắt Dận, representing the Mekong Delta's Ba Xuyên Province, opened the proceedings by invoking the spirit of the assassinated critic of Nguyễn Cao Kỳ, Trần Văn Văn. Then, as one eyewitness recorded, he "unveiled [a] bust of [Trần Văn] Văn which was placed in front of [the] Speaker's podium, and implied that to compromise on transitional arrangements would be [a] betrayal of [Trần Văn] Văn. Several deputies protested [Nguyễn Đắt] Dận's demagoguery."44 Arguably South Vietnam's most prominent southern politician and an emblem of southern regional identity, Trần Văn Văn had been prone to speculating about secret northern alliances to control the south between Hà Nội, the Ngô family, and northern Đại Việts and Catholics. ${ }^{45}$ Exaggerated though they may have been, his suspicions of sinister northern conspiracies reflected the widespread southern anxiety about northern intentions that had informed successive Struggle Movement uprisings and contributed to the delight of the crowds that had turned out to hail the Ngô family's passing. It was seen as a near certainty in southern political circles that Trần Văn Văn's December 7, 1966 assassination had been carried out by the military to silence Nguyễn Cao Kỳs most outspoken civilian critic, and the defiant anti-military and anti-northern implications of Nguyễn Đắt Dận's performance were obvious to all present. ${ }^{46}$ And though the bust was ordered removed after the morning session, a group of southern deputies later retrieved it, waiting until the afternoon's final vote to once again place it next to a large incense burner at the front of the hall before pointedly swearing an oath to uphold and defend the constitution. ${ }^{47}$ These acts of competing performative symbolism, conducted by rival political and religious blocs whose mutual antagonism crystallized during the Ngô Đình Diệm era, reflect the depth and persistence of the polarization that the late president helped engender. The struggle for the constitution, therefore, was the latest salvo in an ongoing regional and religious struggle. 
With the constitution finally ratified on April 1, the Assembly turned to drafting political party legislation in anticipation of the upcoming votes for a new president, Senate, and Lower House in September and October respectively. Here too, Ngô Đình Diệm's toxic legacy would complicate the already delicate process of reconciling South Vietnam's bewildering array of regional and religious axes. Initially scheduled for resolution in the spring of 1967, Assembly debate on the political parties law lingered well into the summer, prompting an exasperated US Embassy to recommend using "what influence we can bring to bear on both the Government and the Assembly to persuade them to write a good party law" before the election. The primary obstacle, the Embassy noted, was that "the Vietnamese are... familiar with 'political parties' which are essentially devices for control of the population. These include Diem's National Revolutionary Movement [Phong trào Cách mạng Quốc gia], Nhu's Republican Youth [Thanh niên Cộng hòa], and various communist mass organizations. The Vietnamese ... know well the kind of party represented by Ngo Dinh Diem's Can Lao." 48

To alleviate such fears, a 1967 newspaper campaign featured a series of editorials extolling the need for political parties, both to impose order in the new electoral system and to organize its hopelessly factionalized anticommunists against the Communist Party—by some distance South Vietnam's only party with a national grassroots presence. Tư Do [Freedom], a newspaper known for its northern Catholic sympathies, acknowledged, for instance, that parties suffered in the eyes of "suspicious people" from the fact that they "have had a very bad reputation in the past"-a clear reference to Ngô Đình Diệm’s Cần Lao. "But what was this past if it was not in the hands of colonialists and dictators?" the paper inquired rhetorically, before insisting that "the political atmosphere in Vietnam will be lively and bright when there is an open regime. Vietnamese parties should then cease organizing in secrecy and in silence.... There is no reason to be suspicious of any political party when one loves democracy and when there is already a worthy regime." 49

Lingering suspicions of the Cần Lao were not so easily assuaged, however, as no less a figure than President Nguyễn Văn Thiệu admitted in November while contemplating forming a new pro-government party. Although he "obviously needed the nucleus for a political party to support the government," the president explained to new US Ambassador Ellsworth Bunker, he 
"did not want it to be identified as his personal instrument in view of the still fresh memories of Diem and the Can Lao Party." 50 Instead, Nguyễn Văn Thiệu opted in the spring of 1968 to assemble the Coalition [Liên minh], a loose partnership of pro-government groups, insisting again in July that he "did not want to repeat Diem's mistakes." ${ }^{51}$ But despite this initial discretion, the looming spectre of a revived Cần Lao meant that even as Nguyễn Văn Thiệu consolidated power over the Lower House, helped by extensive bribery funded by the CIA and Presidential Special Assistant Nguyễn Cao Thăng, it was not until July 17, 1969, almost two years after the elections, that the political party statute was finally rammed through the National Assembly-and then, in spite of many deputies' grave reservations. ${ }^{52}$

Even more important for holding elections was the Election Law itself, the subject of an equally heated confrontation in the Assembly throughout the spring of 1967. Here too, the legislature was roughly divided along regional and religious lines, with southern deputies rallying behind the Movement for the Renaissance of the South [Phong trào Phục hưng miền Nam] (MRS), and northern Catholic and Đại Việt legislators largely supporting the Greater People’s Bloc [Khối Đại chúng] or the much larger promilitary Democratic Alliance Bloc [Khối Liên minh Dân chủ] led by Nguyễn Cao Kỳ's close ally Lê Phước Sang. The subject of particular MRS enmity, Lê Phước Sang embodied for many southerners the tradition of cronyism and corruption that had defined the Ngô Đình Diệm regime and its successors. Faced with the prospect of Lê Phước Sang's appointment as Assembly Chairman, deputy Võ Long Triều declared that should the nomination proceed, he would "resign immediately and apply for Lao citizenship; keeping Vietnamese citizenship with an Assembly Chairman like him would be too shameful for me to bear." 53

Scheduled for passage by the end of the April, the Election Law stalled when MRS deputies demanded increased campaign funds for prospective candidates, and runoff provisions in the presidential race to counter what they saw as a military tactic of dividing votes between as many civilian candidates as possible. Here the opposition won rare sympathy from the US Embassy. No doubt overestimating the military's popularity or, at the very least, its ability to manipulate results in one-on-one contests against anti-communist civilians, the United States also advocated run-offs to 
forestall the possibility of secretly communist-backed candidates prevailing against a divided anti-communist field. ${ }^{54}$ But while the opposition successfully calculated it could win constitutional concessions by leveraging pressure on Nguyễn Cao Kỳ to present President Lyndon Johnson with an approved draft of the constitution during their March 20 meeting in Guam, the military was determined not to give in when it came to the Election Law. ${ }^{55}$ Eager to maximize already substantial administrative advantages, and to project resolve to Armed Forces Council hardliners who opposed further concessions to civilians, Nguyễn Cao Kỳ began applying the stick to deputies who rejected the covert financial carrots offered to those who supported the government. In April, MRS-affiliated politicians like Phan Quang Đán began voicing a litany of allegations against the government, including threats of physical violence from pro-military deputies, menacing anonymous phone-calls, grenades mailed to the houses of MRS members, and newspapers refusing to publish opposition pieces for fear of government reprisal. ${ }^{56}$ And in the Assembly, "to put further pressure on deputies' votes" as MRS member Lý Quí Chung recalls, National Police Chief and Military Security Service Director Nguyễn Ngọc Loan, one of Nguyễn Cao Kỳ’s most loyal partisans, took to patrolling the balcony during Assembly sessions, conspicuously brandishing his revolver while imbibing six-packs of beer. ${ }^{57}$ Intimidated but still unbowed, the opposition deputies continued to hold out. Then, during the May 12 Assembly session, demonstrators from the $\mathrm{CCB}$, which had earlier spearheaded the "supreme being" protests, once again surrounded the Assembly, unfurling anti-opposition banners and chanting "down with the National Assembly." Inside the chamber, deputies abandoned the Election Law debate to take turns denouncing what they regarded as an obvious military campaign to harass them, eventually forcing Assembly Chairman Phan Khắc Sửu to adjourn the proceedings. At this point, the crowd gathered outside attempted to storm the Assembly, smashing windows and kicking down doors before finally being dispersed by riot police..$^{58}$

Convinced the military was once again employing its favored tactic of collaborating with sympathetic northern Catholic parties to stage apparently spontaneous civilian demonstrations, the State Department contemplated intervening more forcefully. But in the end, having already implicitly warned 
Nguyễn Cao Kỳ not to assassinate prominent civilians like Trần Văn Hương or Phan Quang Đán, the United States ultimately determined that further American pressure only risked provoking the military into abandoning the elections altogether. ${ }^{59}$ Tellingly, the State Department, consistently frustrated by its inability to choreograph South Vietnamese politics in spite of massive American military and financial commitments, ordered a study following the elections to find "ways we can more efficiently exert leverage on [the] newly elected GVN [Government of Vietnam] to maximize [the] latter's performance in [the] post-election period." ${ }^{60}$ Meanwhile, the government made a concerted effort, backed by a radio and newspaper campaign, to crack down on pro-military deputies' chronic absenteeism from Assembly sessions. Their absenteeism meant there were not enough promilitary members in the house to vote in favor of government legislation, and this was no small factor in the opposition's successful protracted resistance. ${ }^{61}$ And with these last obstacles removed, the Assembly finally passed the Election Law on June 15, eliminating the run-off provisions, and, in a nod to its virulently anti-communist supporters, adding the far-reaching Article 11(9) disqualifying candidates "who have directly or indirectly worked for communism or pro-communist neutralism or in the interests of communism." ${ }^{2}$

Meanwhile, though the campaign was not formally scheduled to begin until August, Nguyễn Cao Kỳ wasted little time instructing Nguyễn Ngọc Loan to, as the CIA reported, "put into conspicuous action his belief in using government resources to promote Ky's bid."63 Reports from the countryside of a wave of threats, harassment, and the demotion or transfer of rival candidate supporters, among other underhanded tactics, soon reached the capital, prompting prospective civilian contenders to implore the US Embassy to intervene to guarantee a fair election. ${ }^{64}$ Trần Văn Hương, for instance, informed Ambassador Bunker that he "kn[ew] for certain that word-of-mouth orders have gone to province chiefs and district chiefs to rig the election in favour of Ky and Thieu." "These and other tactics were used in the Diem regime," he continued, "and [I] fear they will be employed again." 65 Phan Khắc Sửu, considered a leading civilian candidate along with Trần Văn Hương, was equally suspicious, informing the embassy that Nguyễn Cao Kỳ and Nguyễn Văn Thiệu were "pressuring province chiefs to ensure a heavy vote for their ticket, and General Loan is doing the same to 
provincial police chiefs." ${ }^{\prime 66}$ And Hà Thúc Ký, leader of the Revolutionary Đại Việt faction [Đại Việt Cách mạng Đảng] (RDV), complained of widespread withholding of voter registration cards by the military: "even Mai Thọ Truyền [Trần Văn Hương's running mate] can't get his voting card," he exclaimed. Although post-election cooperation would be essential, Hà Thúc Ký continued, "such cooperation would be difficult if [the] election [was] not honest." 67 When press censorship was relaxed somewhat on July 20 (despite having been officially proscribed by the constitution since April 1), an outpouring of critical articles followed voicing similar concerns, with Thời Đại [Time], for instance, asserting that while Trần Văn Hương would surely win a fair election, "suspicion is justified after experiences acquired from Diemstyle election farces." 68

The embassy, still committed to a military victory, publicly downplayed the allegations while reiterating its official policy of strict non-interference in the campaign. Behind closed doors however, there was growing concern that Nguyễn Cao Kỳ was ignoring Ambassador Lodge's direct April 17 warning that "it is important that no one be given any real grounds for complaining that there had been any abuse of the police power. The Vietnamese people resent the abuse of police power, and this was perhaps the greatest single factor in the wave of public emotion against Diem and Nhu in 1963." 69 No longer able to deny that the implications of such an obvious reference to the manner of Ngô Đình Diệm's demise had failed to produce the desired effect, Ambassador Bunker informed President Johnson on June 14 that "Loan has begun systematically summoning police and military security officers from throughout the country in order to instruct them on how to assure that Ky is elected."7o

Before it had even formally begun then, the election had already lost much of its credibility in the eyes of the civilian opposition, the very people whose loyalties the entire exercise had been intended to recover. "Nobody believed the election would be carried out honestly," Lý Quí Chung recalled. At best it amounted to "a chance for people opposed to the government to express our points of view, and apply stronger pressure against military dictatorship and the war." ${ }^{11}$ In relying so heavily on what were widely referred to as "Ngô Đình Diệm-style" tactics, the military had effectively brought South Vietnamese politics full circle. The generals who one eyewitness records as 
having been "hailed as heroes [and] greeted as saviours of the country" for eliminating Ngô Đình Diệm were now regarded as perpetuating the very system they had once been lauded for dismantling. ${ }^{72}$ And the election, once conceived as the centerpiece of a campaign to reconcile competing anticommunist factions, now seemed like merely a continuation of their struggle, reinforcing rather than resolving the country's acute polarization.

That civilian politicians so reviled the military's "Diệmist" tactics and that they invoked Ngô Đình Diệm's memory so readily in condemning them was perhaps to be expected given that the list of aspiring candidates read like a roll call of men who had endured considerable personal suffering for having dared to oppose the late president. Of the seventeen joint president/vice presidential tickets filed for Assembly approval on July 1, three men-Phan Khắc Sủu, Trần Văn Hương and Trần Văn Lý-had been imprisoned for signing the Caravelle Manifesto. Phan Khắc Sửu and his running-mate Phan Quang Đán had then been subject to beatings and water and electrical torture, and it was for this reason that "speaking very confidentially," Trần Văn Hương informed the embassy, "Suu would be a terrible president. [He] was imprisoned and beaten during his long years as a revolutionary leader, and he is now fuzzy in the head." 73 For their efforts on behalf of the Đại Việt and Nationalist Parties [Việt Nam Quốc dân Đảng] respectively, candidates Hà Thúc Ký and Vũ Hồng Khanh had also been imprisoned under Ngô Đình Diệm, as had Ngô Đình Nhu's one-time lawyer Trương Đình Dzu, disbarred and arrested in 1963 on what was widely regarded as a politically motivated charge of writing a bad check after running against Ngô Đình Diệm in the National Assembly. ${ }^{74}$ Another attorney, Dương Văn Minh's running-mate Trần Ngọc Liễng, had served as defense lawyer to many of Ngô Đình Diệm's aforementioned political prisoners. ${ }^{75}$ Other candidates in 1967 included Phạm Huy Cơ, who had led a delegation of Phan Quang Đán's Free Democratic Party [Đảng Tự do Dân chủ] to foreign capitals seeking assistance in removing Ngô Đình Diệm; Nguyễn Đình Luyện, Minister of Health in the 1960 rebels' abortive antiNgô Đình Diệm cabinet; Âu Trường Thanh, who had advocated overthrowing both Ngô Đình Diệm and Hồ Chí Minh in favor of a "neutralist" [trung lập] government; and Hoàng Cơ Bình, who lost his dental practice after signing the 1960 rebels' manifesto, albeit for very a different reason-his 
frustration over Ngô Đình Diệm's failure to attempt the "liberation" of the North by force-than his colleagues. ${ }^{76}$

More surprising perhaps was the similar manner in which Ngô Đình Diệm featured in the rhetoric of Nguyễn Cao Kỳ's main military rival, the titular Chair of the NLC Nguyễn Văn Thiệu. Circumspect and calculating where Nguyễn Cao Kỳ was flamboyant and spontaneous, Nguyễn Văn Thiệu appealed to conservatives repelled by Nguyễn Cao Kỳs brash attitude and playboy persona, though he was regarded as enjoying less support within ARVN than his competitor. As it grew clear early in 1967 that a selfadministered victory for the military was forthcoming, speculation turned instead to whether Nguyễn Cao Kỳ and Nguyễn Văn Thiệu would field rival presidential tickets, or whether ARVN would settle the confrontation by internally appointing one of the rival generals to serve as its official representative. Undoubtedly, Nguyễn Cao Kỳ's surreptitious groundwork in the countryside had been intended at least as much to gain a head start in thwarting Nguyễn Văn Thiệu as to promote his own prospects. This set the stage for a tense June 15 encounter between Nguyễn Văn Thiệu and Ambassador Bunker, wherein the general, "with considerable emotion," Ambassador Bunker recorded, excoriated his colleague's “attempted use of some members of the armed forces such as General Tri [Nguyễn Bảo Trị] and General Thang [Nguyễn Đức Thắng] in support of his candidacy, the flagrant abuse of censorship, and General Loan's activities." Nguyễn Văn Thiệu "then went on at some length," the ambassador reported, "to stress his view of the imperative need for fair and honest elections if the people were to have confidence in the government. Otherwise... there would be a return to the days of Diem and eventually there would be another coup."77 Well aware of mounting American media criticism of Nguyễn Cao Kỳ’s campaign excesses, Nguyễn Văn Thiệu made his remarks, in part, as a bid to portray himself as a savvier and more responsible alternative to his impetuous rival, and as a statesman who understood the importance of curating South Vietnam's image for constituents both at home and abroad. But in referring so pointedly to his predecessor's demise, the aspiring president was also raising the stakes by shrewdly employing the embassy's own tactic of invoking Ngô Đình Diệm's fate to levy veiled but unmistakable warnings. Given the turbulent post-Ngô Đình Diệm interregnum, which prompted a by-now-overarching 
US commitment to avoid extra-legal changes of government at all costs, such coup speculation could hardly be dismissed as an idle threat.

This latest salvo in the generals' feud came amid growing ARVN fears that forcibly retired general Dương Văn Minh, whose effective captivity in Bangkok "violates [the] language of [the] constitution and electoral law," as Ambassador Bunker put it, would attempt to force his way back to Sài Gòn to contest the military for the presidency. ${ }^{78}$ Unlike the other civilian candidates, men unknown to the vast majority of South Vietnam's mostly rural population, Dương Văn Minh enjoyed national prominence and considerable prestige. His esteemed reputation stemmed almost entirely from popular association as the symbol of anti-Ngô family resistance, and it persisted in spite of his own deposal, forced retirement, and exile shortly thereafter. A southern Buddhist vocal in supporting peace initiatives, Dương Văn Minh functioned as an iconic opposite of Ngô Đình Diệm and his military successors, and he was held to be the only figure with sufficient stature to unite South Vietnam's chronically factionalized opposition. Accordingly, throughout the Second Republic, he was courted by successive opposition operatives hoping to harness his popularity to advance their political ambitions. Few of these men, however, had much regard for Dương Văn Minh’s administrative abilities, preferring to enlist him as something of a cipher whom they could deploy on their behalf from behind the scenes. Trần Văn Đôn, one of Dương Văn Minh's most outspoken public backers, admitted privately for instance that as president, his protégé would be "hopeless," claiming that "even those who supported Minh were fearful of the consequences if he were elected."79 And yet if anything, Dương Văn Minh's lasting appeal despite these perceived deficiencies only underlines his symbolic value as an emblem of southern Buddhist opposition to the Ngô family and its supporters, correspondingly demonstrating once again the depth and persistence of resentment for the Ngô Đình Diệm regime. Certainly, for the increasingly reviled military, the extensive popular admiration for Dương Văn Minh posed an acute threat to the Election Law strategy of exploiting the opposition's otherwise insurmountable fragmentation.

With the Nguyễn Cao Kỳ-Nguyễn Văn Thiệu rivalry and the Dương Văn Minh question coming to a head as the July 1 deadline to file candidacies approached, the military called a top-secret summit for its highest-ranking 
officers at the end of June. The generals quickly determined that Dương Văn Minh could not be permitted to return from Thailand, with Chairman of the Joint General Staff Cao Văn Viên formally requesting on July 6 that the National Assembly disbar his candidacy on the grounds that he posed a National Security threat. ${ }^{80}$ The tactic broke down however, because, as Central Election Council member Lý Văn Hiệp explained, "the complaint by Vien... has not been backed up by further statements, reasons, or documents... and the military has not explained what it means by 'National Security."'"1 Instead, against a backdrop of vitriolic editorials in northern Catholic newspapers demanding Dương Văn Minh’s exclusion, the military seized on a technicality, requesting that his candidacy be eliminated due to running mate Trần Ngọc Liễng's alleged former French citizenship, a violation of Article 53 of the constitution stating that candidates could not have held any citizenship except Vietnamese since birth. ${ }^{82}$ On July 18, with Nguyễn Ngọc Loan again patrolling the National Assembly balcony while liberally imbibing, the military-sponsored Democratic Alliance Bloc turned out in full strength to ratify Dương Văn Minh’s disqualification. Behind the scenes, despite public professions of impartiality, the embassy signaled its approval of Dương Văn Minh's admittedly unconstitutional detention, noting that "the opposition of both the leading military figures and the Catholics [to Dương Văn Minh's candidacy] suggests that a 'Big' Minh victory could put us back in the atmosphere of 1963-64." ${ }_{3}$

Meanwhile, though not formally on the ARVN summit agenda, the Nguyễn Cao Kỳ-Nguyễn Văn Thiệu rivalry remained an elephant in the room throughout the Dương Văn Minh deliberations. Events unexpectedly reached a crisis-complete with bitter accusations, denunciations, and tears -when III Corps Chief and Nguyễn Cao Kỳ loyalist Lê Nguyên Khang revealed that in light of his patron's underhanded campaign tactics, his support for Nguyễn Cao Kỳ had wavered. ${ }^{84}$ ARVN top brass seized on the shift in momentum, imposing a resolution whereby Nguyễn Cao Kỳ and Nguyễn Văn Thiệu would contest the election together on a joint presidentvice presidential ticket, with the latter supplanting the former as the military's choice for president. The resulting all-military slate, an outcome described earlier by the White House as a "disaster" to be avoided at all costs, once again complicated the prevailing interpretation among South 
Vietnamese political observers like Lý Quí Chung that "whichever candidate the United States chose would of course be elected president." 85

Elevated to ARVN heir apparent pending the inevitable administration of his election, Nguyễn Văn Thiệu faced a barrage of media criticism over the military's obvious intervention against Dương Văn Minh, complete with familiar comparisons to the dark days of Ngô Đình Diệm. Nguyễn Ngọc Loan was subject to particular disdain, with pro-southern Tiếng Vang [Echo] condemning his "intimidation of the Assembly" by, as Sông [Life] colorfully put it, reminding legislators that "they could be rounded up and sent to Pleiku for a rest." ${ }^{\prime 6}$ In response, Nguyễn Văn Thiệu addressed accusations of Catholic partisanship during an August 26 press conference by citing his assault on Ngô Đình Diệm's palace as proof of his religious impartiality. This marked the emergence of November 1963 as a recurring campaign issue, employed in subsequent elections by candidates of all persuasions as rhetorical shorthand to position themselves on either side of South Vietnam's indelible regional and religious divides. ${ }^{87}$

Of course, invoking Ngô Đình Diệm’s ouster as evidence of patriotism hardly endeared Nguyễn Văn Thiệu to northern Catholic Ngô family loyalists, though by now the GSF had already committed the votes it controlled to supporting the ARVN slate. Other Catholic groups, however, were yet to be persuaded. Nguyễn Ngọc Biên, leader of the CCB in Bình Thuận where some thirty thousand Catholics resided, complained to a US Embassy contact that the GSF had been "bought off" by the military. He said his followers would instead "follow our conscience," which in Nguyễn Ngọc Biên's case meant siding with southern Buddhist Trần Văn Hương, who he saw as "sympathetic to Catholic interest[s] and, just as important, free of any of the taint of corruption which surrounds the present government." Moreover, Nguyễn Ngọc Biên explained, "a Catholic president won't worktoo many people remember Ngô Đình Diệm." Rather than make his allegiance public, Nguyễn Ngọc Biên confided that he would instead mount a covert word-of-mouth campaign on Trần Văn Hương's behalf, to avoid "difficulties with the authorities." 88

As expected though, ARVN overcame these reservations on Election Day, securing victory-albeit with just 34 percent of the vote-despite vast financial and administrative advantages, and rampant electoral fraud. The 
big surprise was a runner-up finish for Trương Đình Dzu, who shrewdly waited until after his candidacy was approved before launching an effective and resonant radio campaign calling for immediate peace talks with the communists. Prosecuted immediately after the election on currency trading charges dating back to 1962 (which even the embassy regarded as politically motivated), Trương Đình Dzu was again placed under indefinite "protective custody,” as Nguyễn Văn Thiệu put it, following the 1968 Tết Offensive, and formally charged three months later with advocating contact with the National Liberation Front. Both instances resulted in waves of protest in the United States, and served to further delegitimize the new constitutional system in the eyes of many South Vietnamese. ${ }^{89}$

Carried out in the challenging context of a brutal ongoing war, the outcome of the election was mixed at best. At the very least, it had "legitimized, legalized and civilianized the old military regime," Trần Văn Tuyên posited in Chính Luận [Political Discussion] newspaper, and provided a basis for bringing an end to the chaos that, "because there had been no relationship between the government and the people," had characterized the past four years..$^{90}$ Other observers however, such as Senate candidate and future Ambassador-to-Laos Hoàng Cơ Thụy, were skeptical of even this basic feat: "the constitution of 1956, adopted under Diem, was a very reasonable document in itself," he pointed out, "but, as used by Diem, it became an instrument of an authoritarian government." While he had "every hope for the new constitution," Hoàng Cơ Thụy was "more concerned over the manner in which it is applied by Vietnamese leaders in the future." 91 And when it came to the fundamental problem of political polarization, even the more sanguine Trần Văn Tuyên harbored grave doubts. "President Ngô Đình Diệm’s biggest and most basic mistake," he wrote, "was not knowing how to unite national forces ... the prerequisite condition for success in any undertaking." "I am not optimistic," he continued, "like those who say that if we have a constitution and an assembly, we can have democracy and if we have a popularly elected regime, we can have peace... I worry that this Second Republic is deficient at its very beginning and that its existence is seriously threatened at its very birth."92

Conceived in part as a means of reconciling anti-communist South Vietnam's complex overlapping regional and religious poles, the election was 
nearly undone by the very tensions it had been intended to resolve, if anything serving to aggravate rather than alleviate Catholic-Buddhist and civilian-military rivalries. Unsurprising for an exercise contested by factions that emerged and largely defined themselves in response to Ngô Đình Diệm's divisive rule, pro- and especially anti-Diệmist allegory and rhetoric and featured heavily, with candidates positioning themselves by invoking competing interpretations of his legacy. A Chính Luận commenter, for instance, described a country cleaved between those who "wanted order after the chaos that followed November 1, 1963," and those who "feared dictatorship ... and were compelled to find a way to prevent the recurrence of a second [Ngô Đình] Diệm.” The Second Republic, he proposed, amounted to a series of symbolic concessions to the latter camp: "Did [Ngô Đình] Diệm connive at corruption and abuse? In that case, we have a watchdog with broad powers to eradicate corruption ... Did he stifle freedom of speech? Then censorship must be avoided, at least regarding the press." 93 In turn, voter expectations and reactions were likewise conditioned by impressions of Ngô Đình Diệm and his government. As the 1967 campaign to restore legitimacy and constitutional rule reveals, South Vietnamese politics in the Second Republic were dominated by the former president's looming posthumous presence, with ongoing debates about his memory mirrored in the basic configuration of its polarized political scene. Of course, it would take more than a shoddily rigged election to overcome such entrenched hostilities, but, as Trần Văn Tuyên wearily concluded, "in the midst of the current political chaos, having something in hand is better than void and nothingness."94

\section{The Neo-Cần Lao and the Ngô Đình Diệm Revival}

Either content to back the military or wary of a triggering a backlash by selecting another Catholic president, Catholic organizations instead devoted their efforts to the concurrent Senate election, somewhat obscured by the clamor surrounding the heated presidential campaign. Taking advantage of a hopelessly divided field (with forty-eight ten-member slates competing for six places), an Ấn Quang election boycott, and a disciplined parish-level network that could deliver mass turnout for pre-approved candidates, northern Catholic groups succeeded in electing all three of their sponsored 
slates, along with a largely northern sympathetic fourth list fronted by the RDV's Nguyễn Ngọc Kỳ. ${ }^{95}$ So decisive was the victory that some prominent northern Catholics such as Xây Dưng [Construction] newspaper publisher Nguyễn Quang Lâm "seemed even a little embarrassed" by the results, the Embassy recorded. "Two Catholic slates would really have been enough, three would have been just right, but four are a bit too much, posing potential danger to the 'equilibrium of the nation,"' he reportedly remarked, noting that he had already "counseled Catholic senators against forming a bloc in the Upper House."96 Eager to avoid provoking lingering Ngô Đình Diệm-era sensitivities to perceived Catholic conspiracies, Nguyễn Quang Lâm also published a series of editorials insisting that there had been nothing sinister about the Catholic slates' good showing. ${ }^{97}$

The publisher's calls for restraint would go largely unheeded, however, with his colleagues in the legislature proving rather less judicious in exercising their new powers. As Nguyễn Văn Thiệu assumed the presidency, his position remained far from secure, with Vice President Nguyễn Cao Kỳ still enjoying considerable sympathy within the military, and with much of the civilian opposition too distressed by the nature of ARVN's victory to consider cooperating with the president. Calculating that the United States would not accept another military coup (which effectively eliminated Nguyễn Cao Kỳ’s primary means of recourse), Nguyễn Văn Thiệu initially opted to court the northern Catholic-dominated National Assembly, helping to enhance his image as a sober, responsible statesman who respected the new constitution. But the informal northern Catholic bloc that controlled the Upper House was determined to exact a substantial price in exchange for their support, leveraging Nguyễn Văn Thiệu's initial weakness into political capital, which they wielded against a succession of politicians they regarded as either too southern or too soft on communism.

The first to fall at the Senate's behest was Prime Minister Nguyễn Văn Lộc, a southern Nguyễn Cao Kỳ supporter whose appointment had been something of consolation prize for the embattled vice president. Pressured into resigning to pre-empt a no-confidence vote in the Assembly, Nguyễn Văn Lộc was replaced in May 1968 by former presidential candidate Trần Văn Hương, in a bid by Nguyễn Văn Thiệu to extend an olive branch to the restive southern opposition. ${ }^{98}$ Instead, the appointment-a "heavy 
disappointment," according to Lý Quí Chung_had the opposite effect of utterly discrediting Trần Văn Hương among southern political observers, with even his former campaign manager Võ Long Triều dismissing him as "an old man with ambition but no knowledge... who understood nothing about the political situation in the south."99 Worse still, the appointment of a second consecutive southern prime minister engendered significant resentment among northern political groups. In a December 1968 conversation with an embassy source, Trần Vỹ and Lê Trọng Quát, both former Ngô Đình Diệm-era officials and current Nhân Xã Party members, warned that Trần Văn Hương's cabinet "consists largely of technicians with no political identity, and Huong's personal cronies." Should the prime minister fail to implement a "broadening of the cabinet to include real nationalist elements like the Nhân Xã, Revolutionary Đại Việts, [and] northern Catholics," Lê Trọng Quát continued, "nationalist political elements will have no choice but to strive for Huong's removal, which they could bring about within six months." ${ }^{100}$ As it turned out, Lê Trọng Quát had overestimated the northern parties' political strength-but only by two months. On August 22, 1969, amid mounting Assembly attacks against the prime minister, Nguyễn Văn Thiệu requested Trần Văn Hương's resignation, replacing him with retired general Trần Thiện Khiêm and bringing the fleeting era of civilian prime ministers to an abrupt end. ${ }^{101}$

Even former Ngô Đình Diệm-era officials were not spared the Assembly's wrath, particularly in the Foreign Ministry which, in a bid to improve South Vietnam's belligerent image abroad, had started to issue tentative peace positions intended mainly for international consumption. Trần Văn Đỗ, serving his second stint as foreign minister (a post he had held earlier until 1955), was excoriated by Assembly militants after suggesting that the government regard negotiations with the NLF as an internal matter, similar, he noted, to how Ngô Đình Diệm had managed the Hòa Hảo and Cao Đài religious groups. ${ }^{102}$ Accused in the Senate of "creating difficulties for the Assembly in rousing the spirit of the people," "committing a sin against the nation and the people," and "[being] confused like a little child," Trần Văn Đỗ was ultimately forced from office in May 1968. ${ }^{103}$ A Caravelle Manifesto signatory however, he had undoubtedly always been suspect in the eyes of the northern Catholic-controlled Senate. 
His replacement, Trần Chánh Thành, on the other hand, was not only a former Cần Lao member but also the architect of Ngô Đình Diệm's notoriously excessive "Denounce the Communists" [Tố cộng] Campaign. ${ }^{104}$ But despite impeccable anti-Communist credentials, Trần Chánh Thành was also quickly targeted for parliamentary censure after redoubling his predecessor's efforts by calling for a "policy of presence" in neglected neutral countries like France, Cambodia, Indonesia and India before the Vietnam Council on Foreign Relations, a new information service established to promote South Vietnam abroad and counter the communists' global public relations success. ${ }^{105}$ Trần Chánh Thành countered by successfully charging Tư Do [Freedom] publisher Phạm Việt Tuyền with libel for printing Senator Trương Tiến Đạt's allegation that he was "a senior member of the Community Party." 106 But his July 12, 1969 suggestion to foreign journalists that non-communist NLF members could theoretically participate in elections without contravening Article 4 of the Constitution (prohibiting "every activity designed to publicize or carry out Communism") prompted renewed Assembly accusations that he was making "concession after concession" to the other side. ${ }^{107}$ Replaced with more lasting effect in August 1969 by another former Cần Lao member, Senator Trần Văn Lắm, Trần Chánh Thành represented yet another victim of the relentless hyper-partisanship that plagued the early Second Republic.

Even the shock of the 1968 Têt Offensive brought only a brief respite from the bitter sectarian infighting, with an initial wave of anti-communist solidarity inspiring South Vietnam's parties and political groups to explore methods of uniting against the suddenly immediate communist threat. But as the violence gradually subsided, so too did the impetus for political cooperation. The fledgling coalitions that emerged in response to the Têt Offensive quickly aligned along familiar partisan axes, amounting to little more than loosely organized rival blocs replicating established competing political constellations. Thus, when Trần Văn Đôn invited the GSF to join his National Salvation Front [Mặt trận Dân tộc Cứu nguy] coalition, Nguyễn Gia Hiên refused because, as he reportedly explained to a CIA asset, "no Catholics can participate in a political organization that includes An Quang Buddhists ... [and] that includes among its officers General Mai Huu Xuan, who killed former President Diem." ${ }^{108}$ Instead, the GSF opted along with the 
RDV and Nhân Xã parties to enter Nguyễn Văn Thiệu's pro-government National Social Democratic Front [Mặt trận Quốc gia Dân chủ Xã hội] (NSDF), likewise established in response to the Tết Offensive, hoping to secure cabinet positions and other attendant powers and privileges assumed to be on offer as rewards for supporting the president. Predictably, the formation of a state-sponsored front dominated by northern Catholic parties led to renewed fears of "Diệmist" politics, with even Prime Minister Trần Thiện Khiêm warning of the perils should the NSDF be perceived as "a semiclandestine pro-government organization along the lines of the Can Lao."109 And sure enough, a spurned Trần Văn Đôn seized on the symbolic occasion of South Vietnam's National Day [Ngày Quốc Khánh] (the November 1 anniversary of Ngô Đình Diệm's ouster) to warn against Buddhist alienation, echoing his complaints to the US Embassy that the NSDF was compromised from the start by excluding "the people who made the coup against Diem in $1963 \ldots$ and the most important religious element in the country, the Buddhists." 110

It was in this atmosphere of persistent sectional antagonism that the Nhân Xã Party made its debut on the South Vietnamese political scene. Though not the only political organization led by former Cần Lao partisans -indeed, Nguyễn Gia Hiên regarded rumored initiatives by Foreign Minister Trần Văn Lắm and former Ngô Đình Diệm-era intelligence director Trần Kim Tuyến as much greater threats than Nhân Xã to the primacy of the GSF-Nhân Xã stood out as the sole party that explicitly promoted Ngô Đình Diệm in its imagery and rhetoric. ${ }^{111}$ Unveiled at Sài Gòn's Thống Nhất Theatre on April 28, 1968, Nhân Xã was the product of years of planning by a number of former Ngô Đình Diệm-era notables, including former Cabinet Minister Trương Công Cừu (the concurrent Chair of the NSDF Policy and Planning Committee); Nguyễn Văn Thuận, the Bishop of Nha Trang and the late president's nephew; and wealthy pharmacists La Thành Nghệ and Ngô Khắc Tỉnh, the latter, Nguyễn Văn Thiệu’s uncle, serving as Minister of Information and later, Education. ${ }^{112}$

Although an unnamed Party spokesman denied in the English-language Saigon Post newspaper that Nhân Xã represented "a rebirth of the former Can Lao Party," his remarks, the US Embassy noted, "will not be widely believed, as it is already fairly common knowledge in Saigon that Nhan 
Xa ... reflects at least one faction of Can Lao leadership." ${ }^{113}$ After all, Nhân Xã Party material bore the familiar red and green of the Cần Lao, and its organizational structure, dominated by former Cần Lao members, borrowed extensively from the Cần Lao model of clandestine cells and secret internal hierarchies, employing its forerunner's tactic of covertly infiltrating existing institutions to achieve de facto control. Thus, "appear[ing] to take considerable satisfaction in renewed activity by former (or present) Can Lao," Presidential Special Assistant (and former Cần Lao member) Nguyễn Cao Thăng boasted to an embassy source that "every political organization worth its salt today... has Can Lao elements. This is simply because only the Can Lao have genuine grassroots organization." ${ }^{114}$ Even the Nhân Xã Party name, which can be translated roughly as "Social Humanist Party," was an obvious allusion to Personalism [Nhân Vị], the Ngô Đình Diệm regime’s guiding ideology.

After staging a series of more modest regional ceremonies to complement the Sài Gòn inauguration, and establishing two newspapers, Thởi Báo [Times], and later, Độc Lập [Independence] to promote its efforts to revive the Diệmist brand, Nhân Xã set its sights on the 1970 Senate Election as a springboard for reclaiming official government sponsorship. Meanwhile, no doubt interpreting his 1969 Ministry of Information appointment as a signal that the Party enjoyed his nephew's good graces, Ngô Khắc Tỉnh hastened to exploit his presidential connections by filling the Ministry's ranks with Nhân Xã partisans. This prompted Ministry Director of Training Phạm Xuân Nùng to complain to a CIA contact about the Party's "plans to use the [Ministry's] training courses to train Vietnam Information Service employees so that when they return to their provincial offices, they can act mainly as Nhan Xa cadres and form the Party's provincial organizations." ${ }^{115}$ Despite significant state resources at its disposal however, the 1970 Election was a disappointment for the Party, which found itself crowded out by a wide array of more-established northern Catholic competitors and unable even to unite behind a single Nhân Xã ticket. Ngô Khắc Tỉnh's list finished a distant fourth (amid rumors of covert government support), falling well short of securing one of three available places, while Trương Công Cừu's slate managed only an eighth place showing. ${ }^{116}$ But if a frustrating 1970 campaign revealed the limitations of overtly emulating the largely disgraced Cần Lao 
brand, Nhân Xã’s publicization of Ngô Đình Diệm's image was an altogether different matter. And in fostering the poignant November 2 anniversary of Ngô Đình Diệm's death (one day after the much more equivocal occasion of National Day celebrated his deposal) Nhân Xã’s bid to redeem the late president came to fleeting fruition in 1971, testament to the complexity of his legacy even as the anti-Catholic anxieties that emerged during his final years in office were again on the rise.

Before 1971, the graves of Ngô Đình Diệm and his brother Ngô Đình Nhu had been unmarked and scarcely attended save for a small crowd of Ngô family friends and relatives who assembled annually on November 2. The 1971 commemorations - which, as we have seen, drew large, emotional crowds to the cemetery and the Sài Gòn Cathedral-appeared to emerge almost spontaneously, surprising many observers with their intensity, and prompting much local and overseas media speculation about what a Diệmist revival might portend. ${ }^{117}$ In fact, the 1971 memorial represented the culmination of a long behind-the-scenes campaign by a Nhân Xã organizing committee led by Party Chairman Trương Công Cừu. November 2, 1969 witnessed the first Nhân Xã-sponsored Ngô Đình Diệm memorial, and by 1971, the Party was attracting high-profile guests like First Lady Nguyễn Thị Mai Anh (a Mekong Delta Catholic), and official support from the Catholic Church and a host of Catholic political organizations. In October 1971, Nhân Xã established a multi-partisan Ngô Đình Diệm Memorial Committee, recruiting powerful allies including the GSF and the Vietnamese Confederation of Labor [Confédération Vietnamienne du Travail], headed by staunch Ngô Đình Diệm supporter and former Cần Lao executive Trần Quốc Bửu. The Committee was chaired by Father Nguyễn Văn Thịnh, who revealed to a CIA source that he "hope[d] the Diem Memorial Committee will form the basis for a permanent political organization which would play a paramount role in Vietnamese life in the near future ... [and] perhaps lead to the formation of a permanent alliance whose guiding spirit would be the life of President Diem." ${ }^{118}$ Undoubtedly a factor in the wildly successful 1971 Sài Gòn commemorations, these influential partnerships also enabled Nhân Xã to expand its efforts beyond the capital by staging concurrent memorials in Đà Nẵng, Nha Trang and Xuân Lộc. ${ }^{119}$ But while the 1971 event was rather less spontaneous that it appeared, the size and diversity of 
the crowds, which caused severe traffic congestion in Sài Gòn, clearly exceeded the limited reach of Trương Công Cừu and his colleagues alone. ${ }^{120}$ How then to account for this intense but ultimately short-lived Diệm revival?

We must first recall that in 1971, South Vietnam was a very different country than the one forcibly bequeathed by Ngô Đình Diệm in 1963. The escalation of the war and the deployment of millions of American soldiers beginning in 1965 had ushered in a profound transformation of South Vietnamese society. Hoping to foster popular support for the war effort, the United States subsidized a large-scale commodity import program, introducing a wealth of consumer goods but also disrupting the country's economic balance, resulting in rampant corruption, profiteering, and chronic inflation, which devastated South Vietnam's substantial fixed-income class. Meanwhile, as the war in the countryside intensified-roughly four times more bomb tonnage was dropped on South Vietnam than North Vietnam between 1965 and 1975 - millions of displaced rural South Vietnamese fled to the cities for shelter, overwhelming local authorities and generating severe traffic, sanitation and poverty concerns. ${ }^{121}$ By 1970, the US Embassy reckoned, Sài Gòn had become the most densely populated settlement in the world, plagued by "generalized urban discontent caused by rising prices, overcrowding and inadequate public services, and frictions on the political scene," which rendered the city "more volatile than it has been for some time." 122 A piece by Nguyễn Đình Thiều in Sống (arrayed beside a photospread showing pornography stalls on Lê Lợi Street) rechristened the city "Sàighềnh" [maelstrom], describing its jarring transition from charming capital to squalid metropolis, replete with swindlers, gangs, addicts and thieves. 1968, the author proclaimed, was the "year of 'cave' [slang for 'prostitute'] inflation" [Sài Gòn 1968 là năm lạm phát cave]. ${ }^{123}$ Meanwhile, nationalist South Vietnamese of all stripes recoiled in horror at the infusion of American culture, luxury goods and largesse. As the prominent southern Catholic intellectual Lý Chánh Trung affectingly observed:

The dominance of the American Empire, under the guise of national sovereignty, has a profoundly and comprehensively different character than the dominance of classical empires. It can deface even the very soul of a people... The day that the people of the South accept America's permanent "defense of 
our freedom" is the day when our freedom can only be a prefabricated freedom produced in America and imported here under the brands "Coca" or "Pepsi" Cola. We will have a Pepsi system, Pepsi government, Pepsi education, Pepsi culture. We will have the freedom to starve and the freedom to fatten our bellies drinking Pepsi-Cola-a-go-go! Whoever dreams of a future like that for our country can go ahead and dream. But as for me, because I don't know how to drink Pepsi-Cola, I think that: the Americans can donate any kind of object, but they cannot donate freedom. Freedom cannot be an aid commodity. There is no Pepsi-Cola freedom! $!^{124}$

Lý Chánh Trung's remarks reveal another feature of the Second Republic-spiralling war-weariness and anti-Americanism among even staunchly anti-communist South Vietnamese. "Our peasants," wrote Information Minister Tôn Thất Thiện, "will remember their cratered rice fields and defoliated forests, devastated by an alien air force that seems at war with the very land of Vietnam. Villagers will remember their hamlets uprooted from the earth, all to no purpose. And our city dwellers and intellectuals will mark how, while saving Vietnam, a half-million American soldiers are suffocating it with their fantastic wealth, their gadgetry, their promiscuous virility, and their destructive innocence."125 This widespread consternation over American political, economic and cultural dominance was aggravated by recurring incidents where US soldiers shot or ran down Vietnamese pedestrians while driving past them. In the Central Vietnamese town of Quy Nhơn, the December 7, 1970 killing of a high-school student by errant gunfire from a passing US truck sparked two days of student riots, forcing local officials to declare a curfew and deploy the provincial militia to restore order. Scarcely a month later, a second Quy Nhơn teenager was fatally shot on January 16 by a stray bullet from American troops tasked with sinking contaminated food cans with rifle fire. January 21 saw a local schoolteacher gunned down by a soldier from the 173rd Airborne Brigade, and on February 9, two more Quy Nhơn children were shot to death by passing American troops. Three days later, a second round of rioting kicked off in the city, with a series of mobs, each several thousand strong, surrounding the Provincial Headquarters; placing the deceased children's coffins in the province chief s office; torching the entire fleet at a US transport depot; overturning and igniting two American buses to immobilize the Quy Nhơn airfield; and 
blockading the highway and threatening to burn any approaching US vehicles. ${ }^{126}$

While Quy Nhơn was perhaps especially misfortunate, its experience was hardly unique. In Huế, after two Vietnamese youths were shot dead by US troops in September 1971, hundreds of students marched through the city carrying banners demanding immediate US withdrawal, Nguyễn Văn Thiệu's resignation, and condemning "Bloodthirsty Americans." One US Jeep was burned, an American reporter was pelted with stones, and Vietnamese police were confronted by students hurling Molotov cocktails. That same week saw US vehicles in Quảng Ngãi surrounded by South Vietnamese veterans demanding cash payments and prisoner releases, while an American security guard who broke a disabled veteran's wooden arm during a confrontation in Đà Nẵng found himself swarmed by dozens of fellow veterans, who pulled the pins from their grenades until their comrade was promised compensation. ${ }^{127}$ Reports of anti-American outbursts in the provinces often prompted sympathy demonstrations in the capital, where American property, vehicles and installations were by now routinely set upon by bands of Molotov-wielding students. "Anti-American demonstrations always are the easiest to organize," the traditionally conservative Law School Board's Vũ Ngọc Lộc confided to an embassy source, because "no student will defend the Americans in front of his colleagues." ${ }^{128}$ In response, the US military convened a Command Safety Council in December 1970, distributing memos "re-emphasizing the prohibition on indiscriminate firing of weapons," and affirming that "vehicle driving safety is one of the areas of concentration... in improving US-Vietnamese relations." 129 But by autumn 1971 the situation had grown so severe that a fact-finding mission led by Deputy National Security Advisor Alexander Haig advised: "another reason for accelerating US redeployments is the threat posed by antiAmerican incidents." ${ }^{130}$

Against this backdrop of immense civilian casualties, inflation, corruption, squalor, and the proliferation of social vices such as drug abuse and prostitution, the Ngô Đình Diệm era, when considered in hindsight, acquired a powerful nostalgic appeal, reminding people of a simpler time when "the war was small and distant, the Piastre [VNĐ] more valuable, and Americans scarce," as one observer put it. ${ }^{131}$ In a similar manner, the late 
president himself could be recast from aloof, nepotistic autocrat to paragon of a vanishing moral order. Famously unmarried, and by all accounts a devout, even austere figure seen to have personally abstained from the temptations that discredited his more permissive entourage, Ngô Đình Diệm re-emerged during the Second Republic exuding a welcome aura of rectitude and propriety during a period of turbulence and decay.

His budding revival was bolstered by two publications in the spring of 1971. The first, Làm thế nào để giết một tổng thống [How to Kill a President] by Cao Thế Dung and Lương Khải Minh (widely known to be a pseudonym for former intelligence director Trần Kim Tuyến), revisited the events leading up to the fateful 1963 coup, drawing heavily on subsequent disclosures in the Western press. Noting the recent tension between a "movement actively advocating the restoration of the Ngô Đình Diệm regime" and those who saw "restoration of former President Diệm's honor as ... a public negation of the meaning of November $1,1963 \ldots$ a day of revolution and pride," the pair ultimately sided with the latter: "restoring the Ngô Đình Diệm regime in the time and space of 1970 and in the current reality of the South," they concluded, "was nothing but a fantasy in the clouds." 132 Trần Kim Tuyến had, after all, contributed to one of several plots against Ngô Đình Diệm in 1963. Still, their extensive two-volume work complicated prevailing dim impressions of the late president, emphasizing his determination to resist by now-resented American efforts to commandeer the management of the war, and unveiling the critical role played by Ambassador Lodge and the CIA in enabling and orchestrating his demise. After 1963, they noted, "the American Embassy was extremely satisfied in achieving an aspiration... which Mr. Diệm was determined to refuse...the establishment in every Strategic Region of a structure commanded by an American director." ${ }^{133}$

The ripples from "How to Kill a President," however, were dwarfed by the sensational revelations in the Pentagon Papers, the leaked top secret US Defense Department history of American involvement in Vietnam which appeared in the New York Times beginning in June 1971. Rivalled only by coverage of the upcoming South Vietnamese presidential election in Sài Gòn's raucous and still precariously independent press, the Pentagon Papers disclosures touched a nerve with war-weary and increasingly anti-American readers. Much of the coverage focused on exposing American duplicity or 
perceived Vietnamese slights at the hands of the United States. On June 26, Điện Tín [Telegram], a southern-oriented pro-Dương Văn Minh daily, printed what would have been a detailed comparison of American officials' public statements with their leaked private remarks-were it not for extensive government censorship rendering much of the column blank. The irony, undoubtedly, was not lost on Điện Tín readers. Even more evocative was a large (uncensored) cartoon showing a buxom American woman provocatively stripping off an American flag to expose concealed secret documents, an image scorning both American perfidy and licentiousness. ${ }^{134}$ Đối Diện, meanwhile, a leading Catholic opposition journal, published a detailed inquest of alleged American "neo-colonialism" [Thực dân mới] between 1941 and 1954, drawing on the Pentagon Papers for inspiration. ${ }^{135}$ And Điện Tín was one of several newspapers to highlight a sensitive December 1964 encounter in which then-US Ambassador Maxwell Taylor delivered a humiliating rebuke to South Vietnam's ruling generals. ${ }^{136}$

One of the more enduring effects of the Pentagon Papers leaks, however, was to further hasten Ngô Đình Diệm's unlikely rehabilitation. Long derided as $M \tilde{y}$ Diệm [American Diệm] in communist propaganda to underscore his apparent subservience to foreign patrons, the embattled former president reemerged in the Pentagon Papers as a forceful and determined leader who consistently frustrated what were now widely regarded as sinister American efforts to occupy and exploit Vietnam. Hòa Bình [Peace] newspaper, for instance, reworked Trần Kim Tuyến's well-known title with a piece headlined: Người Mỹ làm thế nào để giết một T.T. Việt Nam [How the Americans Killed a Vietnamese President]. ${ }^{137}$ And Xây Dưng devoted the entire front page of its 1971 National Day edition to coverage of "martyred hero Ngô Đình Diệm, who resisted the schemes of foreign states." ${ }^{138}$ Abrupt though it may have been, Ngô Đình Diệm's transition to martyred defender of Vietnamese sovereignty and dignity, an interpretation eagerly promoted by beneficiaries like Nhân Xã, resonated with a South Vietnamese public that had long since tired of the many hardships accompanying the massive American escalation of the war.

In this context, rhetorical invocations of Ngô Đình Diệm's name served a versatile range of objectives, from projecting veiled scorn against the United States to condemning, by extension, the late president's successors, 
who succumbed to foreign enticement where their forerunner had defiantly abstained. Certainly, in the US Embassy, the Ngô Đình Diệm revival was understood to reflect what one report described as "a sublimated antiAmerican nationalism which allows Vietnamese to praise Ngo Dinh Diem's resistance to foreigners without openly denouncing the United States."139 Nhân Xã, which had long relied on anti-American rhetoric-a 1969 Đà Nẵng pamphlet, for instance, warned that "sacrifices of [the] Vietnamese become meaningless if they only benefit American foreign policy"-was quick to deploy their redeemed champion in this manner. ${ }^{140}$ Trương Công Cừu’s 1971 eulogy lauded Ngô Đình Diệm as a "master and benefactor . . . who oppose[d] the impetuous landing of foreign troops in our country," an implied but pointed critique of both Ngô Đình Diệm's successors and their American sponsors. ${ }^{141}$ And Võ Văn Hải, a Lower House Nhân Xã candidate in Sài Gòn who demanded a full state funeral for Ngô Đình Diệm eight years after his death, referred in his platform to "striking proofs... in several recent disclosures in the foreign and domestic press ... that Ngo Dinh Diem lost his life because he had energetically opposed the building of US military bases in this country. He was one of those clear-minded persons who could fathom the cunning and cruel schemes of the foreigners." ${ }^{142}$

Even South Vietnam's largely southern liberal opposition, while much less effusive in evaluating Ngô Đình Diệm's legacy, embraced this line of reasoning to emphasize the Nguyễn Văn Thiệu regime's unfavorable performance in comparison. A June 23, 1971 editorial by Tin Sáng [Morning News], the flagship southern opposition newspaper managed by eminent figures like Ngô Công Đức, Lý Chánh Trung, Hồ Ngọc Nhuận, and Lý Quí Chung, cited the Pentagon Papers as proof of American deceit, while provocatively dismissing Nguyễn Văn Thiệu as a puppet, noting that "in 4000 years of history we have never seen anyone who can be considered a patriot if he sides with foreign states." ${ }^{43}$ And Trần Ngọc Châu, the Lower House deputy whose politically motivated 1970 arrest at Nguyễn Văn Thiệu's behest was ruled unconstitutional by the Supreme Court, issued a similar warning, urging him to mend fences with civilian politicians to resist "being lured by Ambassador Bunker into a most dangerous scheme... [whereby] the United States will possess every means of influencing and subverting the government.... The all-too-shining examples of Mossadegh in Iran, 
Syngman Rhee in Korea and Ngô Đình Diệm and Dương Văn Minh in VietNam are proofs of my observation."144

Published during the height of the 1971 presidential campaign, the Pentagon Papers also triggered the recurrence of Ngô Đình Diệm's fate as a campaign issue, beginning with a July 10 interview with Dương Văn Minh by the Washington Post. One of three candidates along with Nguyễn Cao Kỳ and the incumbent Nguyễn Văn Thiệu, Dương Văn Minh sought to counter mounting evidence that the president's re-election was already pre-arranged by harnessing American public opinion to pressure the State Department into ensuring a fair election (a strategy that Nguyễn Văn Thiệu denounced as "blackmail"). ${ }^{145}$ Domestically, on the other hand, the former general hoped to minimize Catholic voter alienation while still rallying his southern Buddhist base, whose loyalty derived primarily from his status as the face of the Ngô Đình Diệm coup. When, for instance, Washington Post correspondent Peter Jay asked his maid, "to all appearances a completely apolitical Vietnamese lady," who she supported, she immediately replied: "General Minh. He was the one who threw out Diem and Nhu." 146 With these constituencies in mind, Dương Văn Minh informed Jay (in an interview his campaign staff subsequently translated and distributed locally) that, contrary to the Pentagon Papers, he had never contacted the CIA while planning the coup, and that responsibility for Ngô Đình Diệm's death fell on Nguyễn Văn Thiệu who, tasked as a Catholic officer with ensuring the president's personal safety, had inexplicably arrived late at the palace, allowing the Ngô brothers to flee toward their apparently unscripted demise. ${ }^{147}$ Courting the formidably well-organized northern Catholic vote even more aggressively, Nguyễn Cao Kỳ echoed Dương Văn Minh's position that Nguyễn Văn Thiệu's dithering was to blame for Ngô Đình Diệm’s death in Lập Truiờng [Viewpoint], his mouthpiece newspaper, while also condemning antinorthern discrimination. ${ }^{148}$

But it was the incumbent who arguably got the best of the politically charged Ngô Đình Diệm exchanges. Responding to the sensational treatment that the allegations against him were accorded in the press, Nguyễn Văn Thiệu struck back against his opponents during an emotional July 19 press conference. Dương Văn Minh's “cowardly” accusations, he countered, amounted to a dereliction of responsibility, a feeble attempt to pass the buck 
by blaming subordinates for his own failures in command. It was precisely this sort of inept leadership, Nguyễn Văn Thiệu continued, that had seen his rival's hapless tenure cut short after just three months in power. ${ }^{149}$ Clearly vulnerable to such charges of indecision and weakness, which had dogged him ever since his abrupt January 1964 dismissal, Dương Văn Minh attempted an about-face, denying that he had blamed Nguyễn Văn Thiệu for Ngô Đình Diệm's death, and insisting that he had "always accepted full responsibility" for the former president's fate. ${ }^{150}$ Instead, he accused foreign journalists of distorting his remarks, although, given that he had declined to correct the Washington Post interview in the eleven days since its publication, and had even arranged for its translation and circulation, his demurral was hardly convincing. One week later, in an interview with northern Catholic Hòa Bình [Peace] newspaper, Dương Văn Minh attempted further damage control, denying that he had referred to Ambassador Bunker as a "vote rigging instigator," and insisting that he and his fellow generals had never intended for Ngô Đình Diệm to die. ${ }^{151}$

With the outcome of the election-an opportunity to "smash the treasonous, demagogic rhetoric of a minority of defeatists," as one Nguyễn Văn Thiệu campaign planning document put it-once again arranged long before the polls opened, the electoral stakes of the ongoing Ngô Đình Diệm exchanges were limited. ${ }^{152}$ Still, the manner in which the former president's contested legacy flared up during consecutive heated campaigns reveals the extent to which his memory remained a live and extremely sensitive issue in South Vietnam long after his death. As politicians like Dương Văn Minh discovered, striking a public balance acceptable to both sides of the debate was an awkward if not perilous proposition. Much of the difficulty stemmed from the fact that interpretations of Ngô Đình Diệm were in essence statements about the nature of South Vietnam itself, so deeply embedded were the social faultlines that he had done so much to aggravate and enshrine. Taking a definitive stand on the late president often meant signalling an implied position on any number of delicate, vexing questions at the heart of competing visions of how the proper balance of regional, religious, and military or civilian power should lie. Given the acrimonious and intensely polarized political environment that he left behind, Ngô Đình Diệm's legacy could scarcely have been anything but fraught and ambivalent. 
Nothing reflected this ambiguity and discord more than South Vietnam's National Day, an event marked by official if somewhat uneasy public celebration, and followed the next day by more sincere but much more subdued pockets of private mourning. For architects of the ambitiously selfproclaimed "Revolution," the anniversary of Ngô Đình Diệm’s downfall was an opportunity to self-servingly define the coup as a spontaneous manifestation of "pure national spirit," as Trần Văn Đôn put it during his 1969 National Day remarks. ${ }^{153}$ Nguyễn Văn Thiệu's growing list of opponents, which swelled considerably after his dubiously engineered 1971 re-election, also invoked the officially sanctioned symbolism of the occasion, hoping to employ its dwindling ceremonial currency to cast legitimacy on their grievances. On November 1, 1971, for instance, Ấn Quang's Thích Thiên Hoa declared that he "regretted that under the present government, National Day could not be celebrated correctly in accord with the spirit of the 1963 Revolution." 154 Sài Gòn's journalists, on the other hand, had no such stake in edifying the proceedings, and their coverage reveals a much more equivocal affair, replete with abiding bitterness beneath the celebratory public facade. "If we didn't have a National Day on November 1 each year," lamented a Chính Luận [Political Discussion] editorial, "perhaps our divided situation would have faded somewhat. But every year we have a National Day, and when National Day comes, there are people who see each other as enemies." "Are we Vietnamese happy or unhappy on the November 1 Revolution Day?" another headline pondered. ${ }^{155}$

In an atmosphere already imbued with nostalgia for the First Republic's comparative tranquility, the Pentagon Papers heightened the complexity of Ngô Đình Diệm's legacy. And though his image came to function as an icon of South Vietnam's contentious fragmentation, both criticism and praise for the late president routinely emerged from unexpected sources, confounding attempts to classify interpretations of his leadership into simple regional or religious camps. As we have seen, many of Ngô Đình Diệm's Catholic constituents bemoaned the lasting detrimental effects of what was widely regarded, however accurately, as the Diệmist convention of preference for northern and central Catholics, inspiring significant if closeted Catholic political support for sympathetic southern Buddhists like Trần Văn Hương. Additionally, some of South Vietnam's most fervent anti-communists, men 
like RDV Senator Phạm Nam Sách, came to regard Ngô Đình Diệm as responsible for creating the conditions that enabled the communists' rapid rural ascent. ${ }^{156}$ The Communist Party had succeeded in "ruthlessly committing crimes never before seen in the history of humanity," Phạm Nam Sách declared during a 1968 Senate address, because "since 1960, in light of the political and social evils committed by the former Ngô Đình Diệm government, the communists have had a reason to use the pretext of national democratic revolution, taking advantage of discontented people, victims of the Diệm regime, the poor, and even frivolous patriots."157

Former adversaries, on the other hand, spoke of his qualities. Hà Thúc Ký, one of Ngô Đình Diệm's more prominent political prisoners, remembered the former president as "a man with nationalist spirit, who loved his country... though the people around him didn't want to share power with anybody.... Although the Ngô Đình Diệm regime made serious mistakes, especially in the final years, in nine years in power, [it] managed to hold the nation's sovereignty." ${ }^{158}$ Conceding the president's aura of personal propriety, no doubt to further absolve themselves from the enduring controversy that their actions provoked, the architects of the 1963 coup also tended toward complimentary interpretations of Ngô Đình Diệm's character (in contrast to his far more sinister family) in their mostly self-exculpatory memoirs. Tôn Thất Đính’s 20 Năm Binh Nghiệp [Twenty Years a Soldier], one of the more extreme examples of this trend, portrays an impossibly naïve and innocent Ngô Đình Diệm, doomed by a childlike faith in his cunning and duplicitous brothers. ${ }^{159}$ Even veterans of the Struggle Movement, arguably the regime's most formidable non-communist challenger, were sometimes willing to sing his praises. Writer Hoàng Nguyên Nhuận allowed that Ngô Đình Diệm had been "a good nationalist who expelled the last bastion of French colonialists," while no less a figure than Struggle Movement activist Mai Thọ Truyền startled a US Embassy officer during a 1967 conversation by "comment[ing] at length on Diem's good qualities."160

The intricacies of the debate, however, did little to dampen its passion, with rhetorical salvoes exchanged long after the guns of war fell silent. Đỗ Mậu's epic Việt Nam máu lủa quê hương tôi [Vietnam, My Country of Blood and Fire], for instance, created a stir upon its release in 1986 by singling out Vietnamese Catholics, who Đỗ Mậu accused of “indirectly or directly 
pushing the Diệm brothers into a deep pit of sin, resulting in the collapse of their regime and their assassination." "Because the Ngô Đình Diệm government saw the people as a means to serve the regime," he continued, "it came to see the people as an enemy.... and was thus compelled to exterminate the Hòa Hảo, attack the Cao Đài, and finally, take up arms against the Buddhists. The ultimate goal of this endeavor was to Catholicize the people of the South, and grant the Catholic religion a monopoly on the throne." Reflecting the manner in which Ngô Đình Diệm came to symbolize much deeper historical animosities, Đỗ Mậu also emphasized the "persistence in space and time of the dogmatic and monopolistic spirit of the Roman Catholic Church, and its exploitation of harmonious accords between the colonialists and 'Overseas Missionary Societies' over two centuries in the French empire's policy of conquest." Although "nine years of being favored under the Diệm regime was not long enough to deliver a force for subverting the structure of all national activity and commanding every aspect of the economy, politics, culture, and the defense of the nation," he concluded, "the nine years of the Diệm regime represented a final high point." ${ }^{161}$ In response, former Second Republic Senator Nguyễn Văn Chức published a 622-page rebuttal condemning Đỗ Mậu's use of "uneducated mob rhetoric" to denigrate Catholics, insisting that the Ngô Đình Diệm regime was instead "merely the first victim ... [of the] Buddhist 'Protect Religion' struggle, the first step of a process that toppled all authority in South Vietnam." And "if the Diệm brothers persecuted or repressed Buddhism-and this is merely hypothetical, and not actually the case-then it was entirely their fault alone, and not at all related to the Roman Catholic Church." ${ }^{162}$

Nonetheless, as South Vietnam approached its fateful denouement, a tentative consensus in the hotly contested public discourse on Ngô Đình Diệm began to emerge between these extremes, whereby both the president's personal qualities and political failures were acknowledged simultaneously. Tội nghiệp ông Diệm [Poor Mr. Diệm], a 1970 essay by journalist Lý Chánh Trung, encapsulates this more nuanced interpretation. Reflecting on his first encounter with Ngô Đình Diệm as a student in Belgium, Lý Chánh Trung recalled a man whose death was as tragic as his deposal was imperative. Ngô Đình Diệm, he wrote, was "a gentle and virtuous man who loved his country, 
though he understood nothing about the problems of society... and it seemed like he could only speak and not have a true dialogue with anybody." Ultimately, he concluded, the president had been a tragic figure, whose "basic error was that he believed in his own 'People's Saviour, Wise Leader' legend... which the Americans and a number of his underlings created to take advantage of him.... When he realized it was just an illusion, it was already too late: he died because of that illusion." Still, seven years on, "even victims of the regime... seemed more forgiving than they had been toward Diệm," though of course, Lý Chánh Trung observed, sympathy for Ngô Đình Diệm was made possible only by his absence, which allowed "memories to fade, hatreds to be soothed, and suppressed hidden feelings to be released." "Furthermore," he continued, "the reality of southern society went from bad to worse, creating a tendency for people to remember only the more appealing virtues of the Ngô Đình Diệm government whenever they compare those days with the present." And when it came to Ngô Đình Diệm’s political legacy, Lý Chánh Trung was unequivocal:

To suggest that Ngô Đình Diệm's government was a golden age, and that we only need to emulate him in order to solve the country's problems, like a number of his henchmen are now proclaiming with much fanfare, is truly ridiculous and shameless. Those who shout and weep around the name Diệm are like a flock of crows on a corpse. With their plot to restore a Diệm regime without Diệm so they can gorge themselves on extortion just like before, please let them remember that the current of history never flows backwards. ${ }^{163}$

As we have seen then, owing primarily to factors which became apparent only after his death, Ngô Đình Diệm's reputation underwent a degree of posthumous redemption, his status as defiant if quixotic patriot and beacon of piety accentuated by the corruption and squalor that subsumed South Vietnamese society after his passing. His improved personal standing coincided, however, with a growing consensus shared even by onetime supporters that his record as head-of-state had been disastrous. And when Lý Chánh Trung and others increasingly began to refer to "the Diệm regime without Diệm” [Chế độ Diệm không Diệm] to characterize Nguyễn Văn Thiệu's administration, their intent could scarcely have been less complimentary. 


\section{The "Diệm Regime Without Diệm" [Chế Độ Diệm Không Diệm]}

Perhaps the clearest demonstration of the Diệmist political brand's toxicity was the abrupt and instructive collapse of the Nhân Xã Party. While the party's formation in 1968 had raised wary eyebrows in Sài Gòn, in Central Vietnam, where memories of the confrontation over Ngô family rule were especially raw, the backlash was immediate, and fierce. Đà Nẵng - a city with over four hundred thousand residents but, according to a US Consulate report, "only 450 buildings [with] city water [and] woefully inadequate... refuse collection, paved roads, and public health facilities" - barely managed to contain violent clashes between pro and anti-Ngô Đình Diệm loyalists on National Day, 1972. With resentment already simmering between Mayor Nguyên Ngọc Khôi (the former Cần Lao commander of Ngô Đình Diệm’s presidential guard) and an ARVN garrison that concealed a "secret proBuddhist organization among ARVN officers and men whose pro-Struggle sympathies have retarded their promotion," National Day was inevitably a tense affair in a city once "ruled with an iron hand by the Cần Lao Party under Ngô Đình Cẩn,” as the consulate put it. ${ }^{164}$ The mysterious overnight appearance on Đà Nẵng streets of banners reading "Mourn President Ngo Dinh Diem's death for the fatherland," "The spirit of Ngo Dinh Diem endures forever and the people remember it gratefully as a positive example for all men," and "President Ngo Dinh Diem is immortal," among other slogans, enraged ARVN Buddhists, who made clear their intent to remove the offending banners by force. The timely intervention of Ấn Quang's Thích Minh Tuấn, who privately assured the consulate that the mayor's Nhân Xã-dominated “Đà Nẵng Committee to Defend the Republican Regime" was almost certainly responsible, helped placate the agitated soldiers and prevented street fighting between ARVN and the police, though not before Thích Minh Tuấn likewise made known his determination to "resist anyone who attempts to reverse the 1963 Revolution."165

If a hostile Buddhist reaction against Nhân Xã was to be expected, the frosty reception afforded the party from fellow Catholics was all the more telling, revealing once again the noxious character of Ngô Đình Diệm’s political legacy, whatever his personal merits may have been. Nhân Xã’s July 1968 unveiling in Huế was boycotted by the city's archbishop, while local 
Catholic luminaries like Lower House Deputy Nguyễn Lý Hương and $H y$ Vọng [Hope] publishers Nguyễn Văn Dương and Bùi Thế Cẩn spurned the party's membership invitations. ${ }^{166}$ Nguyễn Gia Hiên likewise vetoed GSF cooperation with Nhân Xã, explaining to a CIA contact that he had quit the Cần Lao years ago "because of its lack of true political organization and inadequate programs." "As a political party," he reportedly remarked, "the Can Lao had been 'lousy."'167 And Sài Gòn Archbishop Nguyễn Văn Bình was no less dismissive when courted by Nhân Xã. "I told them plainly that the Can Lao page of Vietnamese history has been turned," he remarked, warning that Nhân Xã would serve only to help the communists score propaganda victories, and that exclusively Catholic political groups had no chance of succeeding in a majority Buddhist society. ${ }^{168}$

Like so many non-communist parties before it, Nhân Xã also fell victim to fragmentation, with a pro-Nguyễn Văn Thiệu faction led by Ngô Khắc Tỉnh and Lê Trọng Quát abandoning the Trương Công Cửu wing of the party in 1971 to form the People's National Reconstruction Force [Lực lượng Nhân dân Kiến Quốc]. Asked about his departure, Lê Trọng Quát could not resist a parting shot: "the existing concept of the Nhan Xa as a reemergence of the Can Lao is not viable," he replied, "[and] the tradition of secret cadre organization [is] outmoded." ${ }^{169}$ And indeed, despite an impressive turnout for its outwardly apolitical Ngô Đình Diệm memorials, when it came to recruitment, the party struggled to overcome decidedly negative perceptions of their fallen champion's politics. In Phước Tuy Province, for instance, where influential local party boss Phạm Văn Thước served as provincial council chairman and was regarded by the US Embassy as the "most widely respected of local government officials," total Nhân Xã strength in the province stalled at just seventy members. "Most people fear politics," Phạm Văn Thước admitted, "remembering political repression of former times.” Despite rallies in Phước Tuy featuring both Ngô Khắc Tỉnh and Trương Công Cừu, "the educated class," the embassy noted, "continues to view the party with some suspicion. Well aware that Nhan Xa is closely linked to the former Can Lao Party of President Diem's reign, many civil servants appear to hesitate to join the new party." ${ }^{170}$ Similarly, although Nguyễn Văn Thiệu ultimately refrained from formally adopting Nhân Xã as his official government party, his association with senior party officials 
like Ngô Khắc Tỉnh proved controversial. Former Interior Minister Trần Đình Nam, regarded by embassy contacts as an authority on Central Vietnamese politics, proclaimed that inviting Nhân Xã to join the NSDF was a "major blunder." "Nhan Xa is controlled mainly by rich ex-Can Lao people who prospered under Diem," he remarked dismissively. "They have little popular support to give the president and, having access to the coffers of the GVN, the president has no need of their money." ${ }^{171}$ Beset by fragmentation and the lingering stigma of association with Ngô Đình Diệm, the remaining Nhân Xã faction was dealt an abrupt final blow in January 1973 when Trương Công Cừu illegally fled to France, reportedly to help his 17-yearold son evade ARVN conscription. ${ }^{172}$

Spiralling despair over the trajectory of the Nguyễn Văn Thiệu regime also saw the invocation of Ngô Đình Diệm's name as pejorative shorthand for political depravity. When Nguyễn Văn Thiệu outlined plans for a new pro-government party during an April 1969 address to the Assembly, "most senators," an eyewitness reported, "whether speaking in support of the president's initiative or not, expressed concern lest the president repeat the mistake of former President Diem and fashion a pro-government party that would then be used for his personal aggrandizement." ${ }^{173}$ More ominous still were the unconstitutional arrests of high-profile opposition deputies like Trần Ngọc Châu and Ngô Công Đức, with the latter's May 1971 detention prompting a Lower House resolution demanding his release, and the condemnation of his "unacceptable" and "political" confinement even in independent but habitually pro-government Chính Luận and Xây Dựng. ${ }^{174}$ Former Minister of Information Tôn Thất Thiện warned US Embassy officials that the incident marked the "beginning of the end" for the Second Republic, comparing Ngô Công Đức's captivity to the 1960 arrest of Phan Quang Đán at Ngô Đình Diệm's behest. ${ }^{175}$

By now, even senior government officials had started to echo the tenor if not the tone of radical student protesters, whose communiqués routinely accused Nguyễn Văn Thiệu of "re-establishing the despotism of the 1963 Ngo Dinh Diem regime." ${ }^{176}$ In December 1969, Ambassador to the United States Bùi Diễm requested a private meeting “as 'Citizen Diem' rather than ambassador" with veteran diplomat William H. Sullivan, in which he relayed his "concern over the deteriorating political situation which he found in 
Saigon during his recent visit there." Likening the current atmosphere to "the sort of discontent which welled up against President Diem . . in 1962," Bùi Diễm warned that “the catalyst for Diem's ultimate overthrow was relatively minor, but was able to draw on all those other sources of discontent which were already in existence." "His fears were compounded," Sullivan noted, "by [the] comparison which he noted between [the] lifestyles of Thieu and Diem. He felt Thieu was becoming a 'prisoner of the Palace' and that he was 'institutionalizing his natural shyness into official austerity."” Concerned that his American counterparts were "inclined to minimize [the] significance of this situation and concentrate instead on [the] need for 'effective government," Bùi Diễm again ominously "raised a comparison with President Diem, who... was [also] 'effective' right to the end." ${ }^{177}$

No doubt aware that he lacked his predecessor's anti-French and newly uncovered anti-American nationalist credentials while sharing his aloof and uncharismatic image, Nguyễn Văn Thiệu exploited his control over the Supreme Court and National Assembly with legislation effectively guaranteeing his already likely re-election in 1971. The ensuing contest was a public relations disaster, marking a point of no return for the Nguyễn Văn Thiệu regime. Seeking to disqualify Nguyễn Cao Kỳ by compelling candidates to win endorsements from mostly pro-Nguyễn Văn Thiệu assemblymen and province chiefs (a provision he had condemned as unconstitutional when suggested by Nguyễn Cao Kỳ in 1967), Nguyễn Văn Thiệu opted to run unopposed when both Nguyễn Cao Kỳ and Dương Văn Minh dropped out in protest after the palace's written vote-rigging instructions to province and district-level officials inevitably surfaced. ${ }^{178}$ A brief wave of demonstrations by students, veterans, opposition politicians and religious and ethnic minority groups quickly gave way to despondency and sardonic resignation. "Comparisons with Diem are now often heard," the US Embassy reported, while Saigon Post columnist Trần Nam, taking his morning stroll on election day, recorded overhearing the following: “The late President Ngo Dinh Diem,' a wag said, 'could have turned in his eternal resting place to exclaim, 'comrade, you beat me!'” 179

Perhaps the most serious consequence for the incumbent president, however, was the permanent breakdown of his de facto alliance with the northern Catholic political groups that dominated the Senate. By running unopposed, 
Nguyễn Văn Thiệu achieved the unlikely feat of uniting South Vietnam's chronically divided opposition, with the GSF and Greater Republican Masses Party [Chánh Đảng Đại chung Cộng hòa] endorsing a Buddhistsponsored September communiqué calling for his immediate withdrawal. ${ }^{180}$ Motivated both by disgust-political operative Đặng Đức Khôi, for instance, complained to a CIA contact that "he had been a strong supporter of Ngo Dinh Diem until the last few months ... and his revulsion against Thieu is now stronger than his final revulsion against Diem"-as well as a fear of 1964-style scapegoating and reprisals, other Catholic luminaries and organizations lined up to follow suit. ${ }^{181}$ Pax Romana, the Catholic intellectual group that had agonized over its position on Ngô Đình Diệm, was unequivocal when it came to Nguyễn Văn Thiệu, issuing a public statement on September 13 denouncing the election as "lacking in democracy and popular enthusiasm," and warning that "the people have almost lost confidence in Thieu's leadership." The following morning, Sài Gòn Archbishop Nguyễn Văn Bình awoke to find his house surrounded by hundreds of angry parishioners demanding that he revoke his July 31 call for a heavy Catholic voter turnout. After a week of intense grassroots campaigning, the archbishop relented, affirming in a September 22 Xây Dưng interview that "the faithful are duty-bound to oppose elections that are fraudulent and lacking in democracy." 182 "We would like to support Thieu," he explained to Catholic Senator Pauline Nguyễn Văn Thơ, "but we cannot if he continues his present course. He won't give us the chance to help him." ${ }^{183}$ Meanwhile, in the Senate, Huỳnh Văn Cao's northern Catholic-dominated progovernment "Vietnam Sky" [Trời Việt] slate broke ranks, partnering with Senate Chairman Nguyễn Văn Huyền's moderate Catholic Bông huệ [Lily] bloc to pass a resolution, with twenty-eight of thirty-one votes declaring the election to be "against the public will" and "likely to bring overall disaster to South Vietnam." ${ }^{184}$

His re-election secured if forever resented, Nguyễn Văn Thiệu hastened to crush what remained of the opposition. Taking advantage of the 1972 communist Easter Offensive, the president exploited the Emergency Powers legislation he was granted after protracted Senate resistance by imposing Decree Laws 007 and 060, effectively silencing the press and disbarring independent political parties (including all three Senate lists), respectively. 
What little popular sympathy remained for Nguyễn Văn Thiệu promptly evaporated. Speaking to a US Embassy source who "had never seen him so seemingly dejected by a political event," Conservative Đại Việt Senator and Chính Luận publisher Đặng Văn Sung threatened to shutter his newspaper rather than see it become a "prostitute" of the administration. Having supported both the Election Law signatures provision and the Emergency Powers bill, which explicitly stated it could be applied only to matters of defense, security, economics and finance, Đặng Văn Sung now warned that "South Vietnam was entering a new Diem-type dictatorship."185 In Chính Luận, he attempted an uncharacteristically defiant stand, penning an August 11 editorial excoriating the "unconstitutional" newspaper legislation, levelling comparisons with the Ngô Đình Diệm era, and depicting Nguyễn Văn Thiệu as "emerging alone... above a sea of mute, subservient South Vietnamese people." "What do the people think of the true nature of the Second Republic of Vietnam?" he inquired rhetorically, "and what will be the ideal for them if they wish to sacrifice their lives in the struggle against communist dictatorship? Once they review everything, they will realize that nothing remains."186 In response, the government pre-empted the despairing senator's recurring threats to cease publication, seizing the August 11 edition and charging Chinh Luận with violating Article 28(a) ("jeopardizing national security and public order") and Article 29 ("publishing information, documents or arguments aimed at extolling the theories, policies or actions of communism or procommunist neutrality") of the new press code. "Police efforts to confiscate the edition were thorough," remarked the US Embassy, which obtained a secret draft from Đặng Văn Sung himself, "and no copies reached the streets."187

With the media now firmly under executive control, Nguyễn Văn Thiệu turned his attention to filling the political void left by Decree Law 060. Having long since lost patience with the fragmented and quarrelsome political groups marginalized by his recent emergency fiats, Nguyễn Văn Thiệu proceeded to unveil the Democracy Party [Đảng Dân chủ], the long-awaited manifestation of the pro-government party he had hinted at to growing degrees of apprehension since taking office. Like the Cần Lao Party before it, the Democracy Party was divided into overt and covert cells. The party's public façade consisted of popular but mostly powerless public notables, including Party Chairman Trần Minh Tùng, described as "a docile southerner 
who will cause no problems” by RDV Senator Nguyễn Văn Ngãi. De facto party control, on the other hand, was wielded by the clandestine apparatus, helmed by Nguyễn Văn Ngãi and political advisor Nguyễn Văn Ngân and staffed primarily by military and police officials, whose involvement was kept nominally secret in line with constitutional stipulations proscribing their membership in political parties. ${ }^{188}$

Starting in earnest in the fall of 1972, a wave of civil servants and soldiers complained of coercive tactics employed to compel them to join the party, including arbitrary dismissal, prosecution on trumped-up charges, conscription (for government workers) or transfers to insecure communistcontrolled areas. ${ }^{189}$ Nguyễn Bé, the highly regarded Director of the National Training Center [Trung tâm Huấn luyện Cán bộ Quốc gia] in Vũng Tàu, was perhaps the most high-profile victim, dismissed in February 1973 for both refusing to join and refusing to allow the Vũng Tàu school to train Democracy Party cadres. Interviewed shortly after his departure, he declared that "the Democracy Party is intended simply to perpetuate President Thieu in power and has no greater national purpose and no independent ideology that will appeal to the Vietnamese people."190 RDV organizer Nguyễn Bảo, on the other hand, projected blasé pragmatism in response to coerced recruitment of Đại Việt cadre into Democracy Party ranks: "Now we return to the secret ways of the French era ... We Vietnamese are a family-oriented people and, though sometimes necessity forces us to play the whore [the Democracy Party], we always come back to our family [the RDV Party]." Although dismayed by Nguyễn Văn Thiệu's recent “obstruction of free elections,” Nguyễn Bảo professed a surprising degree of confidence in his party's fortunes following Decree Law 060. "Because many Revolutionary Đại Việt members have infiltrated the Thieu regime by 'joining' the Democracy Party," he noted, "the Revolutionary Đại Việt Party is now stronger and has a more intimate understanding of GVN internal workings than before."191

From its inception, the Democracy Party drew predictable comparisons to Ngô Đình Diệm’s Cần Lao. Trần Kim Tuyến, an early Cần Lao architect before turning against his patron, was one of many to observe the obvious parallels, although, speaking to a US Embassy source, he emphasized a fatal flaw in both the Cần Lao and the Democracy Party's genesis: 
Those who want to build parties like the Can Lao or Democracy Party start from the premise that the Communist Party is the source of strength in communist regimes, and that this example should be copied. But they turn the development sequence on its head. Whereas the Communist Party is created first, develops, then seizes power, and finally establishes an administration as an extension of its power, those who established the Can Lao and now want to create a Democracy Party think they can reverse the sequence by having an established administration create a political party. It took some of the Can Lao organizers including himself [Trần Kim Tuyến] four years to see their error, according to Tuyen, while some never did.

The result of repeating the Cần Lao Party's mistakes, the former intelligence director predicted, would be the "exacerbation of corruption, ineptitude and favoritism, which will help the communists." 192 Trần Kim Tuyến joined a litany of former high-ranking Cần Lao officials whose objections to the Democracy Party's forced enlistment were recorded, including former Agriculture Minister Lê Văn Đông, who "sharply objects to the coercive aspects of recruiting;" labor leader Trần Quốc Bửu, who believed “Thieu was making a serious mistake in pressuring civil servants and others to join;" and even Đà Nẵng Mayor Nguyễn Ngọc Khôi, who, despite his enthusiasm for directing state resources to serve Nhân Xã, drew the line at mandatory Democracy Party membership, stating that he was "adamantly opposed to any such effort, citing the example of Ngo Dinh Diem and the Can Lao."193

But for most South Vietnamese observers, the Democracy Party's failings were a matter of substance rather than strategy. And with his apparent embrace of the Cần Lao precedent, Nguyễn Văn Thiệu appeared to put the finishing touches on South Vietnam's political decay, heightening an already pervasive sense that the glimmer of optimism which the Second Republic once represented had been extinguished. No party's fate better reflects this transition than the instructive demise of the Progressive National Movement [Phong trào Quốc gia Cấp tiến], a party that emerged proclaiming its devotion the concept of loyal opposition. Established in 1969, the Progressive National Movement pledged subservience to the president on foreign policy and defense, limiting itself to domestic policy suggestions in a spirit of overall cooperation. Founded against a backdrop of growing concern over Nguyễn Văn Thiệu’s intentions, party elders were undeterred: “They 
wouldn't dare try to close us down and return to the days of President Diem," asserted Chairman Nguyễn Văn Bông during the party's introduction in Biên Hòa Province. ${ }^{194}$ Three years later, the group found itself effectively legislated out of existence by Decree Law o6o. Nguyễn Văn Thiệu was "acting as if he did not need the people with him," concluded despondent Party Secretary General Nguyễn Ngọc Huy, who interpreted the Emergency Powers acts as a clear indication that "the Thieu administration intended to revive the 'Diem dictatorship."'195 Beleaguered Senate Chairman Nguyễn Văn Huyền, “long considered 'Mr. Upper House' for his influence in the chamber," according to a US Embassy report, likewise found his Bông huệ group all but precluded by Decree Law 060 from contesting the 1973 Senate elections. 'They have viewed their role as essentially a 'brake' on the president's natural authoritarianism, and as the last remaining guardians of a robust democratic spirit," concluded an eyewitness account of the group's final Upper House session. "A departing member remarked," the report continued:

that the "noble experiment" in constitutionalism launched in 1967-at American urging, he noted pointedly-was turning sour. He had been surprised in 1967 , he said, at the number of qualified people who "engaged themselves" enthusiastically in the experiment by running for office that year. These were individuals who had earlier withdrawn from political participation in the late 1950s, when Diem's rule began to turn authoritarian. These "good" people are retreating once again, the senator commented, once more waiting for some watershed before engaging themselves. ${ }^{196}$

Long before its final military collapse then, the Second Republic was judged by its most committed proponents to have ended in unmitigated political failure.

\section{An Ambiguous Legacy}

Sài Gòn's Notre Dame Basilica, November 2, 1973. Where emotional crowds had once spilled into the streets, there was now "room in the cathedral for all who came," an observer of the proceedings reported. "About two-thirds of those attending were women," he noted, and "of them, the overwhelming majority were either very old women, or young school girls ... brought in from parochial schools in Gia Đinh's heavily Catholic Hóc Môn District or from Catholic orphanages in the Sài Gòn area. The VIP pews in the front of 
the Cathedral were not filled." With attendance estimated at no more than two-thousand-a far cry from the forty-thousand strong turnout predicted by the People's National Reconstruction Force-the 1973 Ngô Đình Diệm memorial was a decidedly subdued affair. ${ }^{197}$ Ten years after his death, it seemed the wave of nostalgia for Ngô Đình Diệm was subsiding as quickly as it had appeared.

Still, as we have seen, memories of the late president loomed large in South Vietnam's Second Republic, his image serving as an avatar for an era whose appeal was apparent only with hindsight. Far from the shrinking posthumous presence that most accounts of his legacy have presumed, Ngô Đình Diệm remained an indelible symbol after his death, highlighting the political, religious, and regional divisions in South Vietnam. His contested legacy established dynamic patterns of political conflict that endured throughout the Second Republic, and provided yardsticks and a common shorthand vocabulary with which subsequent politicians and political developments were measured. Competing impressions of Ngô Đình Diệm both informed and complicated the challenging process of restoring the state's legal basis, beginning with the constitution and elections of 1967. And whatever their positions on the former president, all parties-from his victims to his passionate if largely self-serving Nhân Xẫ Party championsunderstood that their efforts were a continuation of the conflict instigated by decisions during his final years.

Ngô Đình Diệm has been at the heart of recent scholarship on South Vietnam, much of it echoing earlier Vietnamese-language dialogues that dispelled his presumed subservience to the United States and revealed his considerable agency. But the heated debates over his legacy during South Vietnam's final years have hardly featured in the discussions now taking place among scholars. To evaluate Ngô Đình Diệm’s presidency and to understand the politics of South Vietnam's fateful final period, it is crucial to examine the contemporaneous exchanges that were carried out during those years in speeches, street demonstrations, and across the pages of South Vietnam's cacophonous free press. Among South Vietnamese observers, Ngô Đình Diệm's agency was always more apparent than it has been for generations of English-language scholars, though his contemporaries were also taken aback when the Pentagon Papers revealed the extent 
of his single-mindedness in resisting American interference. Instead, characterized by fluidity and searching ambiguity, their discourses focused on the president's conduct and character, the latter undergoing a startling reinterpretation in response to both the Pentagon Papers and nostalgia for the period before South Vietnamese society's rapid decline. Nonetheless, while many anti-communist South Vietnamese gained a new admiration for Ngô Đình Diệm, they decisively rejected the political institutions he had created, recoiling from what we might call the "Diệmist" political style of centralized clandestine power impervious to crescendos of popular disaffection. As Nguyễn Văn Thiệu soon discovered, a "Diệm regime without Diệm," and thus shorn of the propriety and unwavering patriotism that its namesake retroactively represented, was an overwhelmingly unappealing proposition.

SEAn FEar is a PhD candidate in History at Cornell University. This article is based on a presentation at the sixth Engaging with Vietnam Conference at the University of Oregon in November 2014. The author wishes to thank the two anonymous peer reviewers, as well as Peter Zinoman, Edward Miller, Nguyen Phi Van, Alex-Thai D. Vo, Nu-Anh Tran, Tống Thị Xuyên and Mike Revzin for their comments and suggestions. Research for this article was supported by the Social Sciences and Humanities Research Council of Canada, and the Gerald R. Ford Presidential Foundation.

\section{A B S T R A C T}

Although recent English-language Vietnam War scholarship has devoted considerable attention to reassessing the Ngô Đinh Diệm era, contemporaneous South Vietnamese interpretations of the president's tenure have been largely overlooked. Contrary to prevailing assumptions that his influence ended abruptly with his 1963 murder, Ngô Đinh Diệm was a hotly debated figure long after his death. Moreover, his contested legacy came to symbolize South Vietnam's enduring political, regional and religious schisms, contributing to and reinforcing his country's profound social fragmentation. The fluid and ambiguous memory that Vietnamese had of his time in office had a substantial impact on subsequent political developments, establishing patterned dynamics of political conflict that endured throughout the Second 
Republic and providing conceptual yardsticks against which subsequent politicians and political developments were measured. Ngô Đinh Diệm's fraught symbolic resonance and significant posthumous political impact are therefore crucial dimensions to consider in evaluating his legacy.

K E Y W O R D S : Ngô Đình Diệm, Republic of Vietnam, Nguyễn Văn Thiệu, Religious Politics, Anti-Americanism

Notes

1. "Requiem Mass Held for Late Pres. Diem," Vietnam Press (Morning ed.), no. 5767, November 3, 1971.

2. "Embassy Translation of Truong Cong Cuu Speech," Airgram A-76 from Saigon to Department of State, May 10, 1972, POL 6 VIET S 1970-1973 Central Foreign Policy Files (CFPF), Record Group (RG) 59, National Archives and Records Administration (NARA).

3. For a first-hand account, see Mai Elliot, The Sacred Willow: Four Generations of Life in a Vietnamese Family (New York: Oxford University Press, 1999), 299.

4. See, for instance, Bernard Fall, The Two Viet-Nams: A Political and Military Analysis (New York: Praeger, 1963), 236; Frances FitzGerald, Fire in the Lake: the Vietnamese and Americans in Vietnam (Boston: Little, Brown, 1972), 87-88; David Halberstam, The Making of a Quagmire: America and Vietnam During the Kennedy Era. Revised ed. (New York: Alfred Knopf, 1988): 16-19; Seth Jacobs, America's Miracle Man: Ngo Dinh Diem, Religion, Race and U.S. Intervention in Southeast Asia, 1950-1957 (Durham, NC: Duke University Press, 2004), 26; James M. Carter, Inventing Vietnam: the United States and State Building, 19541968. (New York: Cambridge University Press, 2008), 10-14.

5. Examples include Edward Miller, Misalliance: Ngo Dinh Diem, the United States, and the Fate of South Vietnam (Cambridge, MA: Harvard University Press, 2013); Philip Catton, Diem's Final Failure: Prelude to America's War in Vietnam (Lawrence, KS: University Press of Kansas, 2002); Jessica Chapman, Cauldron of Resistance: Ngo Dinh Diem, the United States, and 1950s South Vietnam (Ithaca, NY: Cornell University Press, 2013); Geoffrey Stewart, "Hearts, Minds and Công Dân Vụ: the Special Commissariat for Civic Action and Nation-Building in Ngô Đình Diệm’s Vietnam, 1955-1957," Journal of Vietnamese Studies, 6, no.3 (Fall, 2011).

6. FitzGerald, Fire in the Lake, 136, cited in Seth Jacobs, Cold War Mandarin: Ngo Dinh Diem and the Origins of America's War in Vietnam, 1950-1963 (Lanham, MD: Rowman \& Littlefield, 2006), 189. 
7. Miller, Misalliance, 202-204.

8. See, for instance, Chính Đạo, "Dẫn nhập" [Introduction], Nhìn lại biến cố 11/ 11/1960 [Looking Back at the November 11, 1960 Incident]. (Houston, TX: Van Hoa, 1997), 7-11.

9. Personalism, based on the work of French philosopher Emmanuel Mounier, was conceived by Ngô Đình Diệm and Ngô Đình Nhu as a means of reconciling capitalist self-interest and Marxist collectivism by emphasizing a communitarian spirit while respecting individual human dignity. Miller, Misalliance, 43, 138.

10. Bùi Diễm, In the Jaws of History (Boston: Houghton Mifflin Company, 1987), 94.

11. Hanh H. Nguyen, Brushing the World Famous: the Story of My Life (Lincoln, NE: iUniverse, 2005), 51.

12. Though the perception that the Ngô Đình Diệm regime had favored Northern and Central Catholics was widespread in the Second Republic, it was something of an exaggeration; as Edward Miller notes, only three of the twenty men who served as generals under Ngô Đình Diệm were Catholic. Edward Miller, "Religious Revival and the Politics of Nation Building: Reinterpreting the 1963 'Buddhist crisis' in South Vietnam," Modern Asian Studies, FirstView Articles. Published online (o8 August 2014). Available on CJO 2014 doi:10.1017/ Soo26749X12000935, 14.

13. Lâm Quang Thi, The Twenty Five Year Century: a South Vietnamese General Remembers the Indochina War to the Fall of Saigon (Denton, TX: University of North Texas Press, 2001): 93, 97.

14. “một tay chân Cần Lao Công giáo thân tín.” Đỗ Mậu, Việt Nam máu lủa quê hương tôi [Vietnam: My Country of Blood and Fire] (California: Hoa Kỳ, 1986), 399.

15. "cuộc binh biến"; "mắt xích cuối cùng của một chuỗi dài nhũng khủng hoảng chính trị và quân sự mà chế độ Diệm phải đối phó với rất nhiều vụng về và thiếu chuẩn bị." Ibid., 436.

16. "ý thức bất mãn"; "độc quyền khai thác tài nguyên quốc gia." Trần Văn Đôn, Việt Nam nhân chứng: hồi ký chánh trị [Vietnam Witness: Political Memoir] (Los Alamitos, CA: Xuan Thu Publishing, 1989), 150-151.

17. David Halberstam, The Best and the Brightest. (New York: The Modern Library, 2001 ed.), 168.

18. Vesak Day is an annual Buddhist holiday commemorating the birth and enlightenment of Gautama Buddha. "sư đàn áp vô nhân." Vũ Văn Mẫu, Sáu tháng pháp nạn, 1963. [Six Months of Buddhist Crisis] (Garden Grove, CA: Giao Diem, 2003), 10; Miller, "Religious Revival," 13-19.

19. Charles Keith, Catholic Vietnam: a Church from Empire to Nation. (Berkeley, CA: University of California Press, 2012), 1-10.

20. Alarmed by their prospects in a communist state, seeking new opportunities, and inspired by the possibility of spiritual renewal in the south, tightly 
organized northern Catholic communities arrived en masse in South Vietnam after the 1954 Geneva Conference. Still, significant numbers of northern Catholics choose to remain, including influential leaders such as Hà Nội Archbishop Trịnh Như Khuê. And those who left were by no means unanimous in supporting the war, as the case of peace activist Nguyễn Mạnh Hà among many others suggest. Peter Hansen. "Bắc Di Cư: Catholic Refugees and Their Role in the Southern Republic, 1954-1959," Journal of Vietnamese Studies, 4, no. 3 (Fall, 2009); Trần Thị Liên, "The Challenge of Peace Within South Vietnam's Catholic Community: a History of Peace Activism," Peace and Change, 38, no. 4 (October 2013).

21. Võ Long Triều, Hồi ký tập hai: Đệ Nhị Việt Nam Cộng Hòa. [Memoirs Volume Two: Second Republic of Vietnam] (Lexington, KY: Người Việt, 2010):32-36, Lý Quí Chung, Hồi ký không tên [Untitled Memoirs] (Thành phố Hồ Chí Minh: Nhà Xuất bản Trẻ, 2004): 112.

22. "Conversation with General Duong Van 'Big' Minh," Airgram A-1140 from Saigon to Department of State, 26 December 1968, POL 27-14 VIET 1967-1969, CFPF, RG 59, NARA.

23. Miller, "Religious Revival," 7-13; Shawn McHale, Print and Power: Confucianism, Communism, and Buddhism in the Making of Modern Vietnam (Honolulu: University of Hawaii Press, 2004): 145-147.

24. Miller, "Religious Revival," 16-17, 35-40, 49-52.

25. Undersecretary of State George Ball, for instance, described Ngô Đình Diệm as "an enormous humiliation" following the Xá Lợi raids. Howard Jones, Death of a Generation: How the Assassinations of Diem and JFK Prolonged the Vietnam War (New York: Oxford University Press, 2003), 315.

26. State to Saigon, August 24, 1963, US Department of State, Foreign Relations of the United States 1961-1963 - Vietnam, 3: 628-629 (hereafter cited as FRUS).

27. JFK to Lodge, August 29, 1963, FRUS, 1961-1963, 4: 35-36.

28. Vinh The Lam, Republic of Vietnam 1963-1967: Years of Political Chaos. (Hamilton, Ontario: Hoai Viet, 2010), 6.

29. Fredrik Logevall, Choosing War: the Lost Chance for Peace and the Escalation of the War in Vietnam. (Berkeley, CA: University of California Press, 1999): 8182, 99-102.

30. "Phải chăng men chiến thắng và danh lợi đã ru ngủ các tướng này để đuia họ đến thất bại?” Vũ Văn Mẫu, Sáu Tháng Pháp Nạn 1963, 13.

31. Quang Minh, Cách mạng Việt Nam thời cận kim: Đại Việt Quốc Dân Đảng. [Modern Vietnamese Revolution: the Dai Viet Party] (Westminster, CA: Văn Nghệ, 2000): 246-252; Keith Taylor, A History of the Vietnamese. (New York: Cambridge University Press, 2013), 591-592. 
32. Vinh The Lam, Republic of Vietnam, 60-65, 110-115; Taylor, 594-597; Jack Langguth, "Saigon Generals Striving to Find a Stable Regime," The New York Times, June 13, 1965.

33. Gerald Hickey, Fire in the Forest: Ethnohistory of the Vietnamese Central Highlands, 1954-1976. (New Haven, CN: Yale University Press, 1982), 99-108, 138-142; Oscar Salemink, The Ethnography of Vietnam's Central Highlanders: a Historical Contextualization, 1850-190o (Honolulu: University of Hawaii Press, 2003), 204. Lê Văn Kim, one of the architects of the 1963 coup, was removed from his position as highlands Land Development Program Director by Ngô Đình Diệm for his opposition to the practice of compensating ethnic minorities with alcohol in exchange for their forcibly expropriated lands. Hickey, 42-45.

34. Logevall, Choosing War, xvii-xxii.

35. Robert J. Topmiller, The Lotus Unleashed: the Buddhist Peace Movement in South Vietnam, 1964-1966. (Lexington, KY: University of Kentucky Press, 2002): 44-69, 130-131; Thích Nhất Hạnh, Vietnam: Lotus in a Sea of Fire (New York: Hill and Wang, 1967), 79-81.

36. Topmiller, The Lotus Unleashed, 125: Trần Ngọc Nhuận, Đởi quân ngũ: ký ưc của niên dư Trần Ngọc Nhuận. [Military Life: Memories of Tran Ngoc Nhuan] (Los Alamitos, CA: Xuân Thư, 1992), 406-407.

37. Telegram 17704, Embassy Saigon to Department of State, February 9, 1967, POL 14 VIET S, 1967-1969, CFPF, RG 59, NARA.

38. "Trong nhũng ngày tháng cuối của Đệ Nhưt Cộng Hòa, nhiều thành viên trong Phong Trào Trí Thức Công Giáo Pax Romana, trong đó có tôi, bàn tán luôn miệng về vấn đề 'khủng hoảng' lãnh đạo của miền Nam khi dủ luận quần chúng bất bình thấy hai người em của Tổng thống Ngô Đình Diệm là Ngô Đình Nhu và Ngô Đình Cẩn đang thực thi một chế độ gia đình trị, phi dân chủ, mất lòng dân khá nhiều. . Tuy nhiên cũng có nhiều anh em trong chúng tôi ủng hộ Tổng thống Ngô Đinh Diệm nên thuiờng đặt ngược câu hỏi: Ngoài Tổng thống Ngô Đình Diệm còn ai là người xứng đáng hơn ông trong việc điều hành đất nước? Câu hỏi không ai có thể trả lời dút khoát." Võ Long Triều, Hồi ký tập hai, 30-31.

39. "Memorandum on Action Program to Promote a Favorable Political Evolution in Saigon," White House to Department of State. January 13, 1967, POL USVIET S 1967-199, CFPF, RG 59, NARA.

40. Edward Lansdale, "Nationalist Politics in Vietnam," pp 52-53. August 17, 1968, POL 15 US-VIET S, 1967-1969, CFPF, RG 59, NARA.

41. Nguyễn Văn Bông, Luật hiến pháp và chính trị học [Constitutional Law and Political Science], (Sài Gòn: s.n., 1971): 580-581; "Với 3 chữ 'Đấng Tối Cao,' dân có gì thắc mắc về Hiến Pháp thì cứ hỏi thắng Quốc Hội L.H.” [Regarding 
the words "Supreme Being," Curious Citizens Should Consult the Constitutional Assembly], Chính Luận [Political Discussion], April 1, 1967; Telegram 21769, Embassy Saigon to Department of State, March 31, 1967, POL 23-8 VIET S, 1967-1969, CFPF, RG 59, NARA; William Tuohy, "New Viet Constitution Becomes Law of Land," The Los Angeles Times, April 1, 1967.

42. R.W. Apple Jr, "Saigon Promulgates New Constitution," The New York Times, April 1, 1967.

43. Telegram 21769, Embassy Saigon to Department of State, March 31, 1967, POL 23-8 VIET S, 1967-1969, CFPF, RG 59, NARA.

44. "Q.H.L.H. vẫn giữ nguyên lập trường”[Constitutional Assembly Maintains its Point of View] Chính Luận [Political Discussion], March 19-20, 1967; Telegram 20724, Embassy Saigon to Department of State, March 18, 1967, POL 15-3 VIET S, 1967-1969, CFPF, RG 59, NARA.

45. Robert Critchfied, The Long Charade: Political Subversion in the Vietnam War. (New York: Harcourt, Brace \& World, 1968), 17-24

46. A 1988 series in Hồ Chí Minh City’s Công An [Police] newspaper would later confirm the official version that Trần Văn Văn was killed by a communist assassin. See Ryan Nelson, The Struggle to Build Viable Vietnamese States, 1947-1966: the Life and Death of Trần Văn Văn. (M.A. Thesis, University of Madison-Wisconsin, 2013), 93-95.

47. Telegram 20761, Embassy Saigon to Department of State, March 18, 1967, POL 15-5 VIET S, 1967-1969, CFPF, RG 59, NARA.

48. "Political Party Law," Airgram A-747 from Saigon to Department of State, June 10, 1967, POL 12 VIET S 1967-1969, CFPF, RG 59, NARA.

49. "nhũng người hoài nghi"; "trong quá khứ, chánh đảng đã tỏ ra tồi quá"; "Nhưng quá khư là gì nếu không phải là quá khứ trong tay thực dân và độc tài?"; "không khí chánh trị ở Việt Nam sẽ sôi động và sáng sủa khi có một chế độ cởi mở. Đảng phái V.N. sẽ không còn tổ chức âm thầm bí mật nũa ... đã yêu dân chủ và đã có chế độ xûng đáng thì không thể ngại gì về đảng phái nũa." "Vấn đề Đảng phái Việt Nam" [The Problem of Vietnamese Political Parties], Tư Do [Freedom], January $7,1967$.

50. Telegram 10424, Embassy Saigon to Department of State, November 11, 1967, POL 12 VIET S, 1967-1969, CFPF, RG 59, NARA.

51. Telegram 32844, Embassy Saigon to Department of State, July 17, 1968, POL 13 VIET S, 1967-1969, CFPF, RG 59, NARA.

52. For the use of CIA funds to influence the Constitutional Assembly, see Thomas L. Ahern Jr., The CIA and the Generals: Covert Support to Military Government in South Vietnam. (Washington, D.C.: Center for the Study of Intelligence, 1998), 45. For an account by a former Lower House deputy of Nguyễn Cao Thăng’s efforts see Lý Quí Chung, Hồi Ký Không Tên, 139. 
53. "tôi sẽ tư chức ngay và xin nhập quốc tịch Lào; giũ quốc tịch Việt Nam với một ông chủ tịch Quốc hội nhu vậy tôi xấu hổ lắm.” Võ Long Triều, Hồi ký tập hai, 28-29.

54. Telegram 23078, Embassy Saigon to Department of State, April 14, 1967, POL 14 VIET S, 1967-1969, CFPF, RG 59, NARA.

55. Lý Quí Chung, Hồi ký không tên, 109-110.

56. Telegram 24275, Embassy Saigon to Department of State, April 28, 1967, POL 14 VIET S, 1967-1969, CFPF, RG 59, NARA.; Telegram 222283, Embassy Saigon to Department of State, 6 April 1967, POL 14 VIET S, 1967-1969, CFPF, RG 59, NARA.

57. "nhằm gây áp lực cho cuộc bỏ phiếu của dân biểu." Lý Quí Chung, Hồi ký không tên, 97; Telegram 1384, Embassy Saigon to Department of State, July 19, 1967, POL 14 VIET S, 1967-1969, CFPF, RG 59, NARA.

58. "Nhóm áp lực vào Quốc Hội vỗ tay vang rền ... Nhiều Ông Nghị lớn tiếng lên án việc gây áp lực" [Pressure Group Applauds ... Many Deputies Loudly Condemn Intimidation], Chính Luận [Political Discussion], May 14-15, 1967; Telegram 25552, Embassy Saigon to Department of State, May 12, 1967, POL 14 VIET S, 1967-1969, CFPF, RG 59, NARA.

59. Telegram 200638, Department of State to Embassy Saigon, May 23, 1967, POL 14 VIET S, 1967-1969, CFPF, RG 59, NARA.; Telegram 222283, Embassy Saigon to Department of State, April 6, 1967, POL 14 VIET S, 1967-1969, CFPF, RG 59, NARA.

6o. Telegram 030020, Department of State to Embassy Saigon, August 31, 1967, POL 15 VIET S, 1967-1969, CFPF, RG 59, NARA.

61. Telegram 29896, Embassy Saigon to Department of State, May 27, 1967, POL 14 VIET S, 1967-1969, CFPF, RG 59, NARA.

62. "Quốc Hội L.H. chịu 3 diểm của UBLĐQG” [Constitutional Assembly Accepts National Leadership Committee's Three Points], Chính Luận [Political Discussion], June 15, 1967; Telegram 24451, Embassy Saigon to Department of State, May 2, 1967, POL 14 VIET S, 1967-1969, CFPF, RG 59, NARA. If strictly upheld, Article 11(9) would have disqualified even head of state and future President Nguyễn Văn Thiệu, the district chief of a Việt Minh youth group in 1946. Nguyễn Văn Thiệu, President of the Republic of Vietnam (Saigon: Việt Nam Cộng Hòa, 1969), 2.

63. Ahern Jr., The CIA and the Generals, 52.

64. Võ Long Triều, Hồi ký tập hai, 70.

65. Telegram 02286, Embassy Saigon to Department of State, August 2, 1967, POL 14 VIET S, 1967-1969, CFPF, RG 59, NARA.

66. "Conversation with Phan Khắc Sửu," Airgram A-68 from Saigon to Department of State, July 28, 1967, POL 18 VIET S 1967-1969, CFPF, RG 59, NARA. 
67. Telegram 04781, Embassy Saigon to Department of State, September 2, 1967, POL 14 VIET S, 1967-1969, CFPF, RG 59, NARA.

68. "Vietnamese Press Activity," Telegram 03738, Embassy Saigon to Department of State, August 16, 1967, POL 14 VIET S, 1967-1969, CFPF, RG 59, NARA.

69. Telegram 23234, Embassy Saigon to Department of State, April 17, 1967, POL 14 VIET S, 1967-1969, CFPF, RG 59, NARA.

70. Ellsworth Bunker, "Seventh Weekly Telegram," June 14, 1967. Printed in The Bunker Papers: Reports to the President from Vietnam, 1967-1973. Douglas Pike ed. (Berkeley, CA: Asia Foundation Institute of East Asian Studies, University of California-Berkeley Indochina Research Monograph Series, 1990), Volume I: 48.

71. "Mọi người đều không tin cuộc bầu củ sẽ diễn ra trung thực"; ". . một dịp dể nhũng người đối lập với chính quyền có cơ hội bày tỏ quan điểm mình, áp lực mạnh mẽ hơn chống độc tài quân phiệt và chống chiến tranh." Lý Quý Chung, Hồi ký không tên, 114.

72. Mai Elliot, The Sacred Willow, 299.

73. Ray Fontaine, The Dawn of Freedom: a Biographical Sketch of Doctor Phan Quang Dan (Brownsville, TX: Pan American Business Services, 1992), 46-56; Trần Văn Đôn, Our Endless War: Inside Vietnam (San Rafael, CA: Presidio Press, 1978), 66-67; Telegram 04784, Embassy Saigon to Department of State, September 2, 1967, POL 14 VIET S, 1967-1969, CFPF, RG 59, NARA.

74. Telegram 187, Embassy Saigon to Department of State, July 3,1967, POL 14 VIET S, 1967-1969, CFPF, RG 59, NARA; Telegram 318, Embassy Saigon to Department of State, July 5, 1967, POL 14 VIET S, 1967-1969, CFPF, RG 59, NARA; Telegram 181, Embassy Saigon to Department of State, July 3, 1967, POL 14 VIET S, 1967-1969, CFPF, RG 59, NARA.

75. Telegram 502, Embassy Saigon to Department of State, July 7, 1967, POL 14 VIET S, 1967-1969, CFPF, RG 59, NARA.

76. Telegram 158, Embassy Saigon to Department of State, July 3, 1967, POL 14 VIET S, 1967-1969, CFPF, RG 59, NARA; Telegram 161, Embassy Saigon to Department of State, July 3, 1967, POL 14 VIET S, 1967-1969, CFPF, RG 59, NARA; Telegram 157, Embassy Saigon to Department of State, July 3, 1967, POL 14 VIET S, 1967-1969, CFPF, RG 59, NARA.

77. Telegram 28170, Embassy Saigon to Department of State, June 15, 1967, POL 14 VIET S, 1967-1969, CFPF, RG 59, NARA.

78. Telegram 29083, Embassy Saigon to Department of State, June 27, 1967, POL 14 VIET S, 1967-1969, CFPF, RG 59, NARA.

79. Telegram 18724, Embassy Saigon to Department of State, 30 November 1971, POL 15-2 VIET S, 1970-1973, CFPF, RG 59, NARA.

8o. "Đại Tướng Minh không được phép về nước để ứng cử Tổng thống” [General Minh Not Permitted to Return to Contest the Presidential Election], Chính 
Luận [Political Discussion], July 7, 1967; Telegram 425, Embassy Saigon to Department of State, 6 July 1967, POL 14 VIET S, 1967-1969, CFPF, RG 59, NARA.

81. Telegram 620, Embassy Saigon to Department of State, July 9, 1967, POL 14 VIET S, 1967-1969, CFPF, RG 59, NARA.

82. For Catholic editorials, see, for example, "Chẳng có gì trái với Dân chủ” [Nothing Contrary to Democracy], Xây Dưng [Construction], July 6, 1967; Trần Ngọc Liễng protested that he had held only French "Metropolitan" status rather than full citizenship, that it had been unwittingly bestowed on him in 1950, and that he had never actively pursued French affiliation. Telegram 620, Embassy Saigon to Department of State, July 9, 1967, POL 14 VIET S, 1967-1969, CFPF, RG 59, NARA.

83. Telegram 620, Embassy Saigon to Department of State, July 9, 1967, POL 14 VIET S, 1967-1969, CFPF, RG 59, NARA.

84. Telegram 1177, Embassy Saigon to Department of State, July 16, 1967, POL 14 VIET S, 1967-1969, CFPF, RG 59, NARA.

85. "Memorandum on Action Program to Promote a Favorable Political Evolution in Saigon," White House to Department of State. January 13, 1967, POL US-VIET S 1967-199, CFPF, RG 59, NARA; "Úng cử viên được người Mỹ chọn đương nhiên sau đó sẽ đắc cử tổng thống." Lý Quý Chung, Hồi ký Không Tên, 105.

86. "biết đâu ông ta chẳng bắt minh lên Pleiku nghỉ mát." "Tiết lộ một âm mưu" [Uncovering a Plot], Sống [Life], July 25, 1967; Telegram 2048, Embassy Saigon to Department of State, July 28, 1967, POL 14 VIET S, 1967-1969, CFPF, RG 59, NARA.

87. “Trung Tướng Thiệu họp báo" [Lieutenant-General Thieu Holds Press Conference], Tư Do [Freedom], August 26, 1967.

88. An estimated two-thirds of the members of Bình Thuận's Catholic community were northern refugees clustered around the provincial capital Phan Thiết, including some 14,00o from Nghệ An Province. "Political Developments in Coastal II Corps for Period Ending August 4, 1967." Airgram A-108 from Saigon to Department of State, 6 August 1967, POL 18 VIET S 1967-1969, CFPF, RG 59, NARA.

89. Telegram 20174, Embassy Saigon to Department of State, February 22, 1968, POL US-VIET S, 1967-1969, CFPF, RG 59, NARA; Charles Joiner, The Politics of Massacre: Political Processes in South Vietnam. (Philadelphia: Temple University Press, 1974), 268. For Embassy view of charges against Trương Đình Dzu see "Arrest of Prominent Vietnamese Lawyer." Airgram A-568 from Saigon to Department of State, March 29, 1963, POL 6-1 S VIET, 1963, CFPF, RG 59, NARA. 
90. "chánh quyền quân nhân cũ đã được hợp thức hóa, chỉnh lý hóa và sắp được dân sự hóa"; "vì giũa chánh quyền và nhân dân không có sự liên hệ." Trần Văn Tuyên. "Vài ý nghĩ về cuộc bầu cừ 3 tháng 9" [A Few Thoughts on the September 3 Election], Chính Luân [Political Discussion], September 16, 1967.

91. "Conversation with Hoang Co Thuy, Leading Candidate on Senate List No. 9," Airgram A-192 from Saigon to Department of State, August 4, 1967, POL 14 VIET S 1967-1969, CFPF, RG 59, NARA.

92. "lỗi lầm căn bản và lớn nhất của tổng thống Ngô Đình Diệm . . . không biết đoàn kết lực lượng quốc gia ... đó là điều kiện tiên quyết thứ nhất của mọi công việc]; [Tôi không lạc quan như nhũng người cho rằng có Hiến pháp, có QH là sẽ có dân chủ, có chánh phủ dân bà̀u là sẽ có hòa bình... tôi lo ngại mà thấy rằng chế độ Cộng hòa thư II là một chế độ tiên thiên bất tức và đời sống của nó bị đe dọa nghiêm trọng ngay tư lúc ra đời." Trần Văn Tuyên, "Vài ý nghĩa về cuộc bầu cử 3 tháng 9."

93. "... mong muốn trật tự vi chịu ảnh hưởng của các vu đảo lộn sau 1/11/1963"; “...e sợ dộc tài ... họ phải tìm một cách ngăn ngưa sự tái xuất của một ông Diệm thư hai"; "Ông Diệm có dung túng cho tham nhũng lộng hành? Nên phải có một cơ quan Giám sát có quyền rất rộng để chống tham nhũng. Ông Diệm có bóp nghẹt tự do ngôn luận? Vậy kiểm duyệt phải được bãi bỏ, it nhất đối với báo chí." Nguyễn Văn, "Chế độ ba tuổi” [The Three-Year-Old Government], Chính Luận [Political Discussion], September 4, 1970.

94. "trong cảnh hỗn mang chính trị hiện thời, có một cái gì trong tay được còn hơn khoảng rỗng, hu không." Trần Văn Tuyên, "Vài Ý nghĩa về Cuộc bầu cừ 3 Tháng 9."

95. Nguyễn Văn Huyền’s Bông huệ [Lily] slate, Nguyễn Gia Hiên's Greater Solidarity Force slate, and Huỳnh Văn Cao's Trời Việt [Vietnam Sky] slate.

96. Telegram 6754, Embassy Saigon to Department of State, September 23, 1967, POL 15-1VIET S, 1967-1969, CFPF, RG 59, NARA.

97. See, for example, "Hoài nghi có lý và hoài nghi vô lý” [Reasonable and Unreasonable Suspicions], Xây Dưng [Construction], September 10-11, 1967.

98. "Change-over Ceremony between Former and New Prime Minister," Vietnam Press, May 26, 1968.

99. "thất vọng nặng nề." Lý Quí Chung, Hồi Ký Không Tên, 118; “. . một ông già có tham vọng mà không có kiến thức... không hiểu gì về tình hình chính trị miền Nam.” Võ Long Triều, Hồi ký Tập Hai, 65.

100. "Neo-Can Lao Nhan Xa Party Presses for Cabinet Changes," Airgram A-1127 from Saigon to Department of State, December 19, 1968, POL 15-1 VIET S 1967-1969, CFPF, RG 59, NARA.

101. "Đại Tướng Khiêm Tân Thủ tướng" [General Khiem New Prime Minister], Chính Luận [Political Discussion], August 24-25, 1969; "Telegram 16998, Embassy Saigon to Department of State, August 22, 1969, POL 15-1VIET S, 1967-1969, CFPF, RG 59, NARA. 
102. Telegram 25453, Embassy Saigon to Department of State, April 23, 1968, POL 15-1 VIET S, 1967-1969, CFPF, RG 59, NARA.

103. "tạo khó khăn cho Quốc hội trong việc động viên tinh thần toàn dân... mang một tội trọng đối với quốc gia dân tộc . . . lúng túng trước vấn đề như một trẻ nít." “Thượng viện buộc Ngoại Trưởng Đỗ phải 'treo áo từ quan”" [Senators Press Foreign Minister Do to "Hang Up His Boots"], Trắng Đen [Black and White], May 5, 1968.

104. Miller, Misalliance, 133.

105. Trần Chánh Thành. Viet-Nam's Foreign Policy and Consolidation of Legitimacy: Briefing Summary of Speech, August 20, 1968. Saigon: Vietnam Council on Foreign Relations, 1969.

106. "một cán bộ Cộng sản có nhiều tuổi đảng." "TNS Trương Tiến Đạt yêu cầu Tổng thống giải nhiệm ngay Ngoại trưởng Trần Chánh Thành vì ông này đã từng là 'Cán bộ Cộng sản có nhiều tuồi đảng”' [Senator Truong Tien Dat Demands President Expel Foreign Minister Tran Chanh Thanh Because He Was a "Senior Member of the Communist Party"], Tư Do [Freedom], December 2, 1968; Telegram 6359, Embassy Saigon to Department of State, April 4, 1969, POL 29 VIET S, 1967-1969, CFPF, RG 59, NARA.

107. "Premier to Reshuffle Cabinet," Vietnam Press (Evening ed.), no. 4933, July 18, 1969; [Mọi hành vi nhằm mục đích tuyên truyền hay thực hiện chủ nghĩa cộng sản đều bị cấm chỉ] "Constitution," Airgram A-559 from Saigon to Department of State, March 27, 1967, POL 15-5 VIET S 1967-1969, CFPF, RG 59, NARA; Telegram 5936, Embassy Saigon to Department of State, March 28, 1969, POL 15-1 VIET S, 1967-1969, CFPF, RG 59, NARA.

108. Intelligence Information Cable 57857, "Decision of Catholic Senators not to Participate in New National Salvation Front," Central Intelligence Agency, February 23, 1968, File: Government of South Vietnam - National Salvation Front 1968-1969 (1), National Security Advisor Files (NSAF), NSC Vietnam Information Group: Intelligence and Other Reports (NSC VIG), 1967-1975, Gerald Ford Presidential Library (GFL).

109. Telegram 22752, Embassy Saigon to Department of State, November 13, 1969, POL VIET S, 1967-1969, CFPF, RG 59, NARA. These suspicions of the NSDF were, it turned out, mostly unwarranted; funded by the CIA to promote political pluralism, the NSDF's coffers were, according to Presidential Special Advisor Hoàng Đức Nhã, largely plundered for personal use by members of the Nguyễn Văn Thiệu government. See Frank Snepp, Decent Interval: an Insider's Account of Saigon's Indecent End Told by the CIA's Chief Strategy Analyst in Vietnam. Twenty-fifth Anniversary Edition (Lawrence, KS: University of Kansas Press, 2007), 15. 
110. "Bài Phát biểu của Nghị sĩ Trần Văn Đôn trong cuộc họp kỷ niệm Cách mạng 63, ngay 30-10-69 tại Sài Gòn" [Address by Senator Tran Van On October 30, 1969, During 1963 Revolution Commemoration] Điện Tín [Telegram], November 1-2, 1969; "Telegram 21879, Embassy Saigon to Department of State, 31 October 1969, POL 15-1 VIET S, 1967-1969, CFPF, RG 59, NARA; Telegram 10063, Embassy Saigon to Department of State, 22 May 1969, POL 7 VIET S, 1967-1969, CFPF, RG 59, NARA.

111. Telegram 25824, Embassy Saigon to Department of State, April 27, 1968, POL 12 VIET S, 1967-1969, CFPF, RG 59, NARA. The short-lived Progressive Republican Movement [Phong trào Cộng hòa Tiến bộ], a third Cần Lao revival effort led by former head of Ngô Đình Nhu's Republican Youth Cao Xuân Vỹ and funded by Nguyễn Cao Thăng, copied the Cần Lao manifesto and internal by-laws, and considered merging with Nhân Xã, though they opted due to political sensitivities to obscure their Cần Lao origins in public. Intelligence Information Cable 44356, "Proposed Reestablishment of Can Lao Political Party," Central Intelligence Agency, February 15, 1969, File: Government of South Vietnam - Nhan Xa Party 1969-1973, NSAF, NSC VIG, GFL.

112. “'V.N. Nhân Xã Cách Mạng Đảng’ ra mắt” [Nhan Xa Party Launches] Xây Duing [Construction], April 30, 1968; Andre N. Van Chau, The Miracle of Hope: Francis Xavier Nguyen Van Thuan, Political Prisoner, Prophet of Peace.

(Boston: Pauline Books and Media, 2003).

113. "New Party Makes Bow," Saigon Post, April 30, 1968; Telegram 26035, Embassy Saigon to Department of State, April 27, 1968, POL 12 VIET S, 1967-1969, CFPF, RG 59, NARA.

114. Telegram 26090, Embassy Saigon to Department of State, March 1, 1968, POL 12-1 VIET S, 1967-1969, CFPF, RG 59, NARA.

115. Intelligence Information Cable 02736, "Nhan Xa Party Members Taking Over Positions of Importance in the Ministry of Information," Central Intelligence Agency, December 11, 1969, File: Government of South Vietnam - Nhan Xa Party 1969-1973, NSAF, NSC VIG, GFL.

116. "Sau cuộc bầu cử: những bài học não lòng" [Heart-Rending Lessons After the Election], Chính Luận [Political Discussion], September 4, 1970; Assessment of Upper House Election Results," Airgram A-255 from Saigon to Department of State, September 19, 1970, POL 14 VIET S 1970-1973, CFPF, RG 59, NARA.

117. "Requiem Mass Held for Late Pres. Diem," Vietnam Press (Morning ed.), no. 5767, November 3, 1971; Robert Shaplen, "Nine Years After a Fateful Assassination - the Cult of Diem." New York Times, May 14, 1972.

118. Intelligence Information Cable 457614, "Formation and Visionary Plans of the Diem Memorial Committee," Central Intelligence Agency, October 29, 1971, 
File: Government of South Vietnam - Nhan Xa Party 1969-1973, NSAF, NSC VIG, GFL.

119. "The Ancien Regime Revisited: Dim Prospects of a Diemist Revival," Airgram A-76 from Saigon to Department of State, May 10, 1972, POL 6 VIET S 1970-1973, CFPF, RG 59, NARA.

120. Shaplen, "Cult of Diem."

121. Holly Hill, James R. Curran, and Gareth Robinson, "Electronic Records of the Air War over Southeast Asia: a Database Analysis," Journal of Vietnamese Studies, 8, no. 4, (Fall 2013): 104.

122. Telegram 5193, Embassy Saigon to Department of State, April 1, 1970, POL 2 VIET S, 1970-1973, CFPF, RG 59, NARA.

123. Nguyễn Đình Thiều, "Sàighềnh: đượi! trọc phú! nhoai nhoai! liền bà con gái đẹp và thợ nhót!” [Saighenh! Nouveau-Riche! Teenage Brats! Beautiful Women and Pickpockets!], Sống [Life], Tuần báo 3, Số Đặc biệt về Sài Gòn [Weekly Edition 3, Special Volume on Saigon], June 29, 1968.

124. "Sự thống trị của đế quốc Mỹ, dưới cái vỏ chủ quyền quốc gia, có tính cách toàn diện và sâu xa sự thống trị của các đế quốc cổ điển. Nó có thể hủy hoại cả linh hồn của dân tộc... Ngày nào mà nhân dân miền Nam chấp nhận cho Mỹ vĩnh viễn 'bảo vệ tự do' của mình, thì tư do đó chỉ có thể là thư tự do tiền chế được sản xuất tại Mỹ và nhập cảng vào đây dưới nhãn hiệu Coca hay Pepsi cola. Chúng ta sẽ tư do nhịn đói và tự do phình bung uống Pepsi-Cola a gogo! Ai có mơ ước môt tương lai như vậy cho đất nước nầy thì cứ mơ ước. Riêng phần tôi, vì không biết uống Pepsi-cola, nên tôi nghĩ rằng: người Mỹ có thể viện trợ bất cứ cái gì, nhưng họ không thể viện trợ tự do. Tự do không thể là món hàng viện trợ. Không có tự do Pepsi-cola." Lý Chánh Trung, "Tự do Pepsi-Cola” [Pepsi-Cola Freedom], Tin Sáng [Morning News], October 19, 1970.

125. Cited in Bernard Weinraub, 'US Impact on Vietnam Called 'Devastating,' New York Times, June 10, 1968.

126. "Quy Nhơn bạo động ngày Thứ 2; 3000 sinh viên xuống đường" [Second Day of Quy Nhon Revolt; 3000 Students Take to the Street] Điện tín [Telegram], February 15, 1971; Telegram 0907, Embassy Saigon to Department of State, January 20, 1971, File: Anti-Americanism (2), NSAF, NSC VIG, GFL; Telegram 2176, Embassy Saigon to Department of State, February 13, 1971, File: AntiAmericanism (2), NSAF, NSC VIG, GFL; Intelligence Information Cable 265531, "Vietnam Situation Report as of 1600 Hours Local Time, February 13, 1971," Central Intelligence Agency, February 13, 1971, File: Anti-Americanism (2), NSAF, NSC VIG, GFL; Henry Kissinger, "Memorandum for the President: Allied Misconduct and Anti-Americanism in South Vietnam," January 27, 1971, National Security Files (NSF), Vietnam Country Files (VCF), Box 152, Folder 1, Richard Nixon Presidential Library (RNL). 
127. Telegram 15016, Embassy Saigon to Department of State, September 18, 1971, File: Anti-Americanism (2), NSAF, NSC VIG, GFL.

128. Telegram 15621, Embassy Saigon to Department of State, September 29, 1971, POL 13-2 VIET S, 1970-1973, CFPF, RG 59, NARA.

129. Telegram 1238, Embassy Saigon to Department of State, January 26, 1971, NSF, VCF, Box 152, Folder 2, RNL.

130. B/Gen A.M. Haig, Jr., "Memorandum for Henry A. Kissinger, Southeast Asia Trip September 20-26, 1971," NSF, VCF, Box 157, Folder 1, RNL.

131. "The Ancien Regime Revisited: Dim Prospects of a Diemist Revival," Airgram A-76 from Saigon to Department of State, May 10, 1972, POL 6 VIET S 19701973, CFPF, RG 59, NARA.

132. "phong trào vận động tích cực để phuc hồi chế độ Ngô Đinh Diệm]; [phục hồi danh dự cho cố Tổng thống Diệm tức là đã công khai phủ nhận ý nghĩa của ngày 1-11-1963 ... một ngày cách mang với niềm tự hào"; "tái lập chế độ Ngô Đình Diệm ở vào không gian và thời gian 1970 và trong thực tại miền Nam nhui hiện nay thì đó chỉ là chuyện giả tưởng trên mây.” Lương Khải Minh [Trần Kim Tuyến] and Cao Vị Hoàng [Cao Thế Dung], Làm thế nào để giết một tổng thống [How to Kill a President]. (Sài Gòn: Đinh Minh Ngọc, 1970): 14, 697-698.

133. "Tòa đại sứ Mỹ rất thỏa mãn vì đạt được ước vọng mà ... ông Diệm quyết tâm tư chối ... thiết lập tại mỗi Vùng chiến thuật một cơ cấu do một giám đốc người Mỹ chỉ huy." Ibid., 14-21, 692.

134. Điện Tín [Telegram], June 26, 1971.

135. The editor's introduction argued that "The movement of American journalists competing to release the 'secret documents' has created a considerable fervor in public opinion, which will obviously have a positive effect toward peace and independence." "Phong trào báo chí Hoa Kỳ thi đua tung ra các 'tài liệu mật' đã làm xôn xao dủ luận không ít và hăn là sẽ có tác dụng tốt cho việc đi tới Hòa bình Độc lập.” Võ Việt Quốc, "Diễn tiến Cuộc Xây Dựng và Phát triển Chính sách Thực dân mới của Mỹ tại V.N. (từ 1941 đến 1954)" [Appearance and Development of an American Colonialist Policy in Vietnam (From 1941 to 1954)] Đối Diện [Face to Face], no. 26, (August 1971): 1-39.

136. Điện Tín [Telegram], June 26, 1971, Telegram 103001, Embassy Saigon to Department of State, June 29, 1971, POL 2-5 VIET S, 1970-1973, CFPF, RG 59, NARA.

137. "Hồ sơ tối mật của Ngũ Giác Đài: Người Mỹ làm thể nào để giết một T.T. Việt Nam" [Secret Pentagon Files: How the Americans Killed a Vietnamese President], Hòa Bình [Peace], July 28, 1971.

138. "Vị Anh hùng tuẫn quốc Ngô Đình Diệm, vì chống lại âm mưu ngoại bang" [Martyred Hero Ngô Đình Diệm, Who Resisted the Schemes of Foreign States], Xây Dựg [Construction], November 1, 1971. 
139. "The Ancien Regime Revisited: Dim Prospects of a Diemist Revival," Airgram A-76 from Saigon to Department of State, May 10, 1972, POL 6 VIET S 1970-1973, CFPF, RG 59, NARA.

140. Telegram 22420, Embassy Saigon to Department of State, November 8, 1969, File: Anti-Americanism (2), NSAF, NSC VIG, GFL.

141. "Embassy Translation of Truong Cong Cuu Speech," Airgram A-76 from Saigon to Department of State, May 10, 1972, POL 6 VIET S 1970-1973, CFPF, RG 59, NARA.

142. "Embassy Translation of the Platform of Võ Văn Hải (Saigon’s First Constituency, August 29, 1971)," Airgram A-76 from Saigon to Department of State, May 10, 1972, POL 6 VIET S 1970-1973, CFPF, RG 59, NARA.

143. "Trong suốt bốn nghin năm lịch sủ VN, chúng ta chuia bao giờ thấy có một nhân vật nào đi với ngoại bang mà lai được lịch sủ ghi tung 'đó là con người yêu nước' cả." "Vụ Nữu Ước Thời Báo với tiền đồn Thế giới Tự do" [The Case of the New York Times, Outpost of World Freedom], Tin Sáng [Morning News], June 23, 1971.

144. Trần Ngọc Châu, "The Statement of Trần Ngọc Châu," printed in The Antioch Review, vol. 30, 3-4, (Autumn 1970 - Winter 1971): 299-310.

145. Telegram 11152, Embassy Saigon to Department of State, July 17, 1971, POL 14 VIET S, 1970-1973, CFPF, RG 59, NARA.

146. Peter A. Jay, "Minh Runs as Peace Candidate but is Keeping his Plans Vague," Washington Post, July 11, 1971.

147. Peter A. Jay, “CIA Lied on Coup, Minh Says,” Washington Post, July 11, 1971.

148. Telegram 11472, Embassy Saigon to Department of State, July 20, 1971, POL 2-5 VIET S, 1970-1973, CFPF, RG 59, NARA.

149. Ibid.

150. Telegram 11600, Embassy Saigon to Department of State, July 22, 1971, POL 14 VIET S, 1970-1973, CFPF, RG 59, NARA.

151. "đầu tầu bầu củ gian lận." "Big' Minh đã lật con tẩy của ông cho mọi người biết" ['Big' Minh Pulls Out the Eraser for Everyone to See], Hòa Bình [Peace], July 28, 1971.

152. "đập tan luận điệu my dân và phản quốc của một thiểu số chủ bại." "Tài Liệu Hướng Dẫn về Việc Lập Kiến Nghị Đệ Trình Tổng Thống," undated, folder 5652, Phủ Tổng thống Đệ Nhị Cộng Hòa (PTTDNCH), Trung tâm Lưu trữ Quốc gia 2 (TTLTQG2).

153. "tinh thần quốc gia thuần túy." "Bài phát biểu của Nghị sĩ Trần Vặn," Điện Tín [Telegram], November 1-2, 1969.

154. Telegram 17427, Embassy Saigon to Department of State, November 2, 1971, POL 2-5 VIET S, 1970-1973, CFPF, RG 59, NARA.

155. "Nếu mỗi năm .. . không có một ngày Quốc Khánh vào dịp 1-11, có lẽ tình trạng chia rẽ đã phai nhạt phần nào. Nhuing mỗi năm lại có một ngày Quốc Khánh, và 
cứ đến dịp Quốc Khánh, lại có nhũng người nhìn nhau nhu kẻ thù." "7 năm cách mạng" [Seven Years of Revolution], Chính Luận [Political Discussion], November 1, 1970; Telegram 17618, Embassy Saigon to Department of State, November 3, 1970, POL 2 VIET S, 1970-1973, CFPF, RG 59, NARA.

156. Phạm Nam Sách created a minor furor when he was quoted in the May 25, 1968 edition of "Construction" [Xây Dựng] accusing a group of southern “intellectuels déracinés” led by Trần Văn Tuyến of "colluding with a foreign power to seek a coalition with the NLF” See Trần Văn Tuyến, “A Matter of Realism," Viet-Nam Enquirer, June 4, 1968.

157. "thảng tay phạm một tội ác chuia tüng có trong lịch sử nhân loại”; "Từ năm 1960, trước nhũng tệ đoan chính trị, xã hội mà chánh phủ của cố Tổng thống Ngô Đình Diệm phạm phải, Cộng sản đã có lý do đem chiêu bài cách mạng dân tộc dân chủ ra lợi dụng nhũng người bất mãn, nhũng nạn nhân của chế độ, nhũng dân chúng nghèo đói, và cả nhũng người yêu nước nông nổi." "Bài Thuyết trình của Nghị sĩ Phạm Nam Sách,” undated (1968), folder 796, PTTDNCH, TTLTQG2.

158. "Ngô Đình Diệm là người có tinh thần quốc gia, có nhiệt tình yêu nước... nhuing nhũng người chung quanh Thủ Tướng không muốn chia sẻ quyền lực với bất kỳ ai ... Mặc dù chế độ Ngô Đình Diệm đã mắc phải nhũng lỗi lầm, nhất là vào nhũng năm cuối cùng, nhuing trong 9 năm cầm quyền, chế độ Diệm đã nắm được chủ quyền quốc gia." Hà Thúc Ký, Sống còn với dân tộc [Surviving with the People]. [S.I.]: Phương Nghi Ấn Hành, 2009: 203, 359.

159. Tôn Thất Đính, 20 năm binh nghiệp: hồi ký của Tôn Thất Đính [Twenty Years a Soldier: Memoirs of Ton That Dinh], (San Jose, CA: Chánh đạo, 1998): 90-91, 220, 352-361, 371-377, 405, 419-420.

160. Hoàng Nguyên Nhuận, "Portrait of the Leader," Vietnamese Engaged Buddhism: the Struggle Movement of 1963-1966. Phạm Văn Minh et al. (Westminster, CA: Văn Nghệ, 2002), 498. Mai Thọ Truyền’s admission was "ironic," Ambassador Bunker noted, "in view of the fact that he was one of the principal leaders of the 1963 'Struggle,' which provided the emotional climate and pretext for the military overthrow of the Diem regime." Telegram 26245, Embassy Saigon to Department of State, May 22, 1967, POL 14 VIET S, 1967-1969, CFPF, RG 59, NARA.

161. “... khối Công giáo Việt Nam đã gián tiếp hay trực tiếp đẩy anh em Diệm sa vào hố sâu tội lỗi để cho chế độ họ bị sup đổ và anh em họ bị sát haị"; "Chính quyè̀n Ngô Đinh Diệm đã xem dân nhu một phương tiện để phuc vụ chế độ, đã phải xem dân nhủ kẻ thù ...vì vậy chính quyền Diệm mới phải tiêu diệt Hòa Hảo, đánh phá Cao Đài, và cuối cùng khai chiến với Phật giáo. Mục đích tối hậu của chủ trương này là để Công giáo hóa nhân dân miền Nam dành cho Thiên Chúa giáo ngôi vị độc tôn”; "... sự nối dài, trong không gian lẫn thời gian, cái tinh thần giáo điều và độc tôn của Tòa Thánh La Mã ... sự khai thác 
nhũng thỏa hiệp nhịp nhàng giũa thực dân và "Hội Truyền Giáo Hải Ngoại" trong chính sách xâm thực của đế quốc Pháp tù gần 2 thế kỷ"; "9 năm được uiu đãi dưới chế độ Diệm chuia đủ lâu để khai sinh một lực lượng khuynh loát hầu hết sinh hoạt quốc gia ở thượng tầng kiến trúc, khống chế mọi khu vực kinh tế, chính trị, văn hóa, quốc phòng của quê hương...9 năm của chế độ Diệm chỉ là cao điểm cuối cùng mà thôi." Đỗ Mậu, Việt Nam máu lủa quê hương tôi, 800-801, 932.

162. "luận điệu của nhũ̃ng phường vô giáo dục"; "Chính quyền Ngô Đình Diệm chỉ là nạn nhân đầu tiên...cuộc đấu tranh mệnh danh 'bảo vệ đạo pháp' của Phật Giáo năm 1963 ... chỉ là bước đầu trong tiến trình lật đổ tất cả các chính quyền tại miền Nam Việt Nam"; "Nếu anh em ông Diệm kỳ thị hoặc đàn áp phật giáo đây chì là giả thuyết chư sư thật không có như vậy - thì đó là hành động và tội riêng của họ, không liên quan gì đến Tòa Thánh La Mã.” Nguyễn Văn Chức. Việt Nam chính sủ hay là nhũng sai lầm và gian trá trong "Việt Nam máu lủa quê hương tôi của Đỗ Mậu” [A Political History of Vietnam, or, the Mistakes and Lies in Do Mau's "Vietnam: My Country of Blood and Fire"], (Falls Church, VA: Alpha, 1992): 12, 410-411.

163. "Tôi có cảm tưởng ông là người hiền lành, yêu nước và có đạo đức độ nhuing lại ... không am hiểu gì hết về các vấn đề xã hội ... Hình nhu ông chỉ có thể nói đuợc một mình chớ không đối thoại thật sự được với aì"; "Cái lỗi căn bản của ông là chính ông đã tin nơi cái huyền thoại 'Cứu tinh dân tộc, lãnh tụ anh minh'... do người Mỹ và một số tay chân bộ hạ tạo ra dể lợi dung.... Khi ông nhận thấy đó chỉ là một ảo tưởng thì đã quá trễ: Ông đã chết vì cái ảo tưởng đó"; "ngay cả nhũ̃ng nạn nhân của chế độ ấy... có vẻ khoan hồng hơn đối với ông Diệm"; "Với thời gian, kỷ niệm đã mờ nhạt, hận thù được xoa dịu, nhũng ẩn ức dồn nén được giải tỏa"; "Trong khi đó, cái thực trang của xã hội miền Nam mỗi ngày thêm xấu xa tệ hại, khiến cho người ta có khuynh hướng chỉ nhớ tới nhũng nết tương đối dễ coi của chế độ Ngô Đinh Diệm, mỗi khi so sánh thời nầy với thời trước"; "Cho rằng chế độ ông Diệm là một thời đại hoàng kim và chỉ cần bắt chước ông Diệm là có thể giải quyết những vấn đề đất nước, nhu một số tay chân bộ hạ của ông đang tuyên bố rùm beng, thì thật là lố bịch và vô liêm sỉ. Nhũng người đang hò hét khóc lóc chung quanh cái tên ông Diệm nhui bầy quạ trên một xác chết. Với cái âm mưu tái lập một chế độ Diệm không Diệm trong đó họ sẽ phè phỡn bòn rút như xủa, xin họ nhớ rằng giòng lịch sủ không bao giờ chảy ngược chiều." Lý Chánh Trung, “Tội nghiệp ông Diệm” [Poor Mr. Diem], Tin Sáng [Morning News], August 21, 1970.

164. "Politics in Danang City," Airgram A-7 from Saigon to Department of State, January 5, 1970, POL 18 VIET S 1970-1973, CFPF, RG 59, NARA.

165. Telegram 15579, Embassy Saigon to Department of State, November 1, 1972, POL 23-8 VIET S, 1970-1973, CFPF, RG 59, NARA; Telegram 15715, Embassy 
Saigon to Department of State, November 3, 1972, POL 15 VIET S, 1970-1973, CFPF, RG 59, NARA.

166. Telegram 32952, Embassy Saigon to Department of State, July 18, 1968, POL 18 VIET S, 1967-1969, CFPF, RG 59, NARA.

167. Intelligence Information Cable 50209, "Efforts of Former Can Lao Members to Build a New Political Party," Central Intelligence Agency, September 23, 1969, File: Government of South Vietnam - Nhan Xa Party 1969-1973, NSAF, NSC VIG, GFL.

168. Telegram 26312, Embassy Saigon to Department of State, May 3, 1968, POL 12 VIET S, 1967-1969, CFPF, RG 59, NARA.

169. "Formation of People's National Reconstruction Force," Airgram A-15 from Saigon to Department of State, February 5, 1971, POL 12 VIET S 1970-1973, CFPF, RG 59, NARA.

170. Phước Tuy roughly corresponded with contemporary Bà Rịa-Vũng Tàu. "Political Parties in Phuoc Tuy Province," Airgram A-42 from Saigon to Department of State, January 30, 1971, POL 18 VIET S 1970-1973, CFPF, RG 59, NARA.

171. "Comments of Dr. Nam on President Thieu's New Alliance," Airgram A-309 from Saigon to Department of State, June 17, 1969, POL 15 VIET S 1967-1969, CFPF, RG 59, NARA.

172. Telegram 4645, Embassy Saigon to Department of State, March 21, 1973, POL 15-2 VIET S, 1970-1973, CFPF, RG 59, NARA.

173. Telegram 7268, Embassy Saigon to Department of State, April 16, 1969, POL 15-1 VIET S, 1967-1969, CFPF, RG 59, NARA.

174. "không bao giờ chúng tôi có thể chấp nhận"; "đòn chính trị." Although affirming its "intense opposition to Ngô Công Đức's demagogic and deceitful political views" [Chúng tôi đã từng kịch liệt chống đối "lập trường chánh trị mị dân, bịp bợm của DB Ngô Công Đức"], Xây Dựng "felt the need to immediately confirm: we can never accept (or ignore) ... the government's behavior towards this individual” [Chúng tôi cần phải xác định ngay rằng: không bao giờ chúng tôi có thể chấp nhận (hay làm ngở) . . . cách xử sự của chánh quyền hiện nay đối với cá nhân ông] "X.D. nghĩ gì về vụ Ngô Công Đức?” [What Does Xay Dung Think About the Ngo Cong Duc Case?] Xây dựng [Construction], June 3, 1971; Chính Luận, meanwhile, described the episode as "a black scar on our so-called legally based democracy" [một vêt đen bôi thêm lên chế độ mệnh danh là dân chủ pháp trị]. "Thêm một vết đen” [Another Black Scar], Chính Luận [Political Discussion], June 4, 1971.

175. Telegram 8983/1, Embassy Saigon to Department of State, June 8, 1971, POL 2-5 VIET S, 1970-1973, CFPF, RG 59, NARA.

176. Telegram 3791, Embassy Saigon to Department of State, March 13, 1971, POL 29 VIET S, 1970-1973, CFPF, RG 59, NARA. 
177. Telegram 000746, State Department to Embassy Saigon, January 2, 1970, POL 15-1 VIET S, 1970-1973, CFPF, RG 59, NARA.

178. See, for instance, George McT. Kahin, "Nixon and the PRG's 7 Points," The American War in Vietnam. Jayne Werner and David Hunt eds. (Ithaca, NY: Cornell Southeast Asia Program, 1993), 58-65.

179. Telegram 16571, Embassy Saigon to Department of State, 16 October 1971, POL 14 VIET S, 1970-1973, CFPF, RG 59, NARA. Trần Nam, “Off the Record: Quiet Polling Day," Saigon Post, October 6, 1971.

180. Telegram 15478, Embassy Saigon to Department of State, September 21, 1971, POL 23-8 VIET S, 1970-1973, CFPF, RG 59, NARA.

181. Intelligence Information Cable 400746, "Plans and Attitudes of Vice President Nguyen Cao Ky and his Presidential Campaign Staff," Central Intelligence Agency, August 13, 1971, File: Government of South Vietnam - Government of South Vietnam - Nguyen Cao Ky 1967-1973, NSAF, NSC VIG, GFL.

182. "Khi nhận thấy có gian lận và thiếu dân chủ thì bổn phận của người tín hũu là phải chống đối." "Đức TGM lên tiếng trong bài phỏng vấn của XD về bầu cử 310" [The Archbishop Speaks Out in Xay Dung Interview About the October 3 Election], Xây Dựng [Construction], September 22, 1971.

183. Telegram 15620, Embassy Saigon to Department of State, September 29, 1971, POL 14 VIET S, 1970-1973, CFPF, RG 59, NARA.

184. Telegram 15537, Embassy Saigon to Department of State, September 28, 1971, POL 2-5 VIET S, 1970-1973, CFPF, RG 59, NARA.

185. Telegram 11660, Embassy Saigon to Department of State, August 9, 1972, NSF, VCF, Box 161, Folder 3, RNL.

186. "Settling the Press Issue with a View to Preparing for a Political Struggle," Chính Luận [Political Discussion], 11 August 1972. (US Embassy Translation). File: Press, 1967-1972 (7), NSAF, NSC VIG, GFL.

187. "Editorial on New Press Decree Law," Airgram A-154 from Saigon to Department of State, August 28, 1972, File: Press, 1967-1972 (7), NSAF, NSC VIG, GFL.

188. "Democracy Party Development," Airgram A-236 from Saigon to Department of State, December 19, 1972, POL 12 VIET S 1970-1973, CFPF, RG 59, NARA. 189. Ibid.

190. "Colonel Nguyen Be Leaves the Vung Tau National Training Center," Airgram A-1 from Saigon to Department of State, March 2, 1973, POL 15 VIET S 19701973, CFPF, RG 59, NARA.

191. "The Revolutionary Dai Viet Party is Alive and Well and Living in Dalat," Airgram A-105 from Saigon to Department of State, August 13, 1973, POL 12 VIET S 1970-1973, CFPF, RG 59, NARA.

192. "Democracy Party Development," Airgram A-236 from Saigon to Department of State, December 19, 1972, POL 12 VIET S 1970-1973, CFPF, RG 59, NARA. 
193. Ibid; Telegram 19961, Embassy Saigon to Department of State, December 28, 1971, POL 15-1 VIET S, 1970-1973, CFPF, RG 59, NARA.

194. "Progressive Nationalist Movement in Bien Hoa Province," Airgram A-537 from Saigon to Department of State, October 29, 1969, POL 12 VIET S 1967-1969, CFPF, RG 59, NARA.

195. Telegram 11632, Embassy Saigon to Department of State, August 8, 1972, NSF, VCF, Box 161, Folder 3, RNL.

196. "The Old Guard Leaves the Upper House," Airgram A-137 from Saigon to Department of State, July 23, 1973, POL 15-2 VIET S 1970-1973, CFPF, RG 59, NARA.

197. “Diem Commemorations Smaller, Generally Pass Quietly,” Airgram A-137 from Saigon to Department of State, November 5, 1973, POL 6 VIET S 1970-1973, CFPF, RG 59, NARA. 